\title{
DEREGULATION AND LABOR EARNINGS \\ IN THE AIRLINE INDUSTRY
}

David Card

NBER Working Paper 5687

\author{
NATIONAL BUREAU OF ECONOMIC RESEARCH \\ 1050 Massachusetts Avenue \\ Cambridge, MA 02138 \\ July 1996
}

I am grateful to Peter Reiss for comments on a much earlier draft, to my colleagues in the Industrial Relations Section for many useful comments and discussions, and to Tom Cunniff, Gordon Dahl, and Jeff Wilder for outstanding research assistance. This paper is part of NBER's research program in Labor Studies. Any opinions expressed are those of the author and not those of the National Bureau of Economic Research.

(C) 1996 by David Card. All rights reserved. Short sections of text, not to exceed two paragraphs, may be quoted without explicit permission provided that full credit, including (®) notice, is given to the source. 


\title{
DEREGULATION AND LABOR EARNINGS \\ IN THE AIRLINE INDUSTRY
}

\begin{abstract}
This paper uses a variety of data sources to study the effect of deregulation on the structure of wages in the airline industry. Microdata from the 1980 and 1990 Censuses show a 10 percent decline in the relative earnings of airline workers after deregulation, with roughly similar declines for industry-specific occupations (pilots and flight attendants) and general occupations (managers and secretaries). Union contract data for pilots, flight attendants and mechanics at the major firms show similar trends in the levels of earnings along with a rise in inter-firm wage inequality -especially for pilots. Finally, data from the displaced worker surveys reveal that airline workers experienced similar wage losses to job-losers from other industries over the 1980s. Taken as a whole, the evidence suggests that the rent premiums earned by airline workers in the regulatory era were relatively modest, and comparable to the wage premiums earned in many other sectors.
\end{abstract}

\author{
David Card \\ Department of Economics \\ Princeton University \\ Princeton, NJ 08544 \\ and NBER
}


The passage of the 1978 Airline Deregulation Act launched a new era in the air transport industry. ${ }^{1}$ After decades of regulation-induced inertia, the number of U.S. airline firms tripled in just a few years. The new entrants competed aggressively with the incumbent airlines, offering lower fares, new routes, and low-cost "no frills" flights. The advent of open competition in the airline industry coincided with a rapid rise in energy prices and a prolonged recession. In the newly deregulated marketplace this combination of supply and demand shocks proved too much for many incumbents: by 1985 the output share of the 11 original "trunk" airlines had declined substantially, and several firms were in bankruptcy. ${ }^{2}$

Deregulation of the product market and the adverse economic conditions of the early 1980s had an immediate impact on the labor market for pilots, flight attendants, and other airline employees. Several of the weaker incumbents negotiated wage cuts with their unionized workers. ${ }^{3}$ Many start-up firms broke with industry tradition by hiring non-union flying personnel and adopting flexible work rules. In a highly publicized move, Texas International (a former "local service" airline) purchased Continental Airlines and then used bankruptcy protection laws to abrogate Continental's union contracts. Some of the profitable incumbents

'Throughout this paper, I use the term "air transport industry" to refer to the group of firms that are legally permitted to carry passengers or cargo in interstate commerce. For a summary of the events leading up to deregulation of the industry, see Keeler (1981), Graham and Kaplan (1982), Bailey, Graham and Kaplan (1985) and Brown (1987). Caves (1962), Eads (1975) and Douglas and Miller (1974) describe the airline industry in the pre-deregulation era. Morrison and Winston (1986) describe the deregulated industry.

${ }^{2}$ Under regulations established in the late 1930s, 11 firms were given the right to operate national or international flight schedules. These were known as "trunk" airlines. Another 13-15 firms were allowed to offer short-haul flights in specific regional markets -- these were known as "local service" carriers.

${ }^{3}$ See Capelli $(1985,1987)$ for a thorough discussion of industrial relations in the airline industry in the early 1980s. 
attempted to lower their marginal costs by instituting lower pay scales for newly-hired employees. Unionized airline workers fought hard against these developments: the industry experienced a series of bitter labor disputes throughout the 1980s.

The post-deregulatory wave of downward pressure on labor costs was anticipated by many analysts, who had argued that the structure of airline regulation, coupled with the high rate of union coverage in the industry, led to super-competitive wages ${ }^{4}$. Indeed, tabulations by Helwege (1992, Table 1) show that airline employees were among the most highly-paid industry groups in the 1960,1970 , and 1980 Censuses. To the extent that workers were able to capture some of the rents generated by airline regulation, one might have expected deregulation to lower equilibrium wages in the industry, especially for the highly unionized industry-specific occupations. Nevertheless, some of the downward pressure on wages in the early 1980s was likely a transitory phenomenon caused by adverse business cycle conditions, high oil prices, and short-run adjustments to the newly competitive environment.

After nearly two decades it is now possible to reach some firmer conclusions on the longrun labor market effects of airline deregulation. ${ }^{5}$ This paper uses a variety of data sources to address two specific questions: How has deregulation affected the level of airline workers' wages, relative to other wages in the economy? And how has deregulation affected the dispersion of wages within the airline industry? With respect to the first question, I find that the relative

\footnotetext{
${ }^{4}$ One of the earliest studies of union wage effects was conducted on airline pilots. Lewis (1961, pp. 99-105) re-analyzed the data used in this study and concluded that airline pilot earnings were 24-30 percent above "competitive" rates in the mid-1950s.

${ }^{5}$ There is an extensive literature on airline deregulation and earnings: see for example Hendricks, Feuille, and Szerszen (1980), Card (1986), Cremieux (1996), and Hirsch and Macpherson (1994a).
} 
earnings of airline employees have declined modestly since 1978: on the order of 10 percent. Perhaps surprisingly, the declines have been similar for most occupation groups. The relative earnings of secretaries and managers in the airline industry fell by about the same percentage as the relative earnings of pilots. Airline mechanics are a notable exception: their relative wages have been roughly constant since the late 1970 s. These patterns suggest that pre-1980 airline wages contained a modest regulatory rent component that was shared by employees in most occupations.

With respect to the second question, the available data show a rise in the dispersion of wages in the airline industry after 1980 . Nevertheless, the increase in inequality in the airline sector is comparable to the economy-wide rise in wage inequality over the past decade (see e.g. Levy and Murnane (1992)). Some of the inter-firm and intra-firm wage differentials that opened up in the early-1980s have been eliminated with the bankruptcy or sale of "low-wagen entrants and the elimination of two-tier wage schedules at the surviving incumbents. While a few lowwage firms still survive, the fraction of employment at such carriers remains small.

Finally, an interesting perspective on the effects of airline deregulation is obtained by studying workers who lost jobs in the industry over the 1980s. Although the fraction of such workers is small, the use of a pooled sample from the six Displaced Worker Surveys conducted between 1984 and 1994 yields an important conclusion. On average, workers displaced from the airline industry experienced very similar wage changes to workers displaced from other industries. Moreover, workers who lost jobs in the airline industry and moved to new jobs in other industries fared as well as those who found new jobs in the airline industry. These findings 
reinforce the conclusion that the effects of deregulation on airline workers' wages were relatively modest.

\section{Regulation and Labor Earmings in the Airline Industry: A Review of Altermative Hypotheses}

There is no general theory of the relation between product market regulation and labor earnings. A widely-held view is that regulation creates potential rents which are then shifted in part to employees. Trade unions may be instrumental in rent shifting and also may play a role in the actual creation of rents by raising costs among regulated firms. ${ }^{6}$ Nevertheless, as Hendricks $(1975,1977)$ has emphasized, the effect of regulation depends on the nature of the product market and on the regulatory process. The predicted effect of a change from a regulated to an unregulated environment also depends on the structure of the unregulated industry. In this section I briefly describe the regulated and unregulated airline industries and summarize some of the possible predictions for the effect of deregulation on labor earnings.

\section{a. The Regulatory Era}

Prior to 1978 airline passenger fares and cargo rates were set directly by the Civil Aeronautics Board (CAB), and entry into the industry was highly restricted. In fact, the $C A B$ allowed no new trunk carriers to enter after 1938, and no new local service airlines to enter after 1951 (Keeler, 1981). In addition to setting prices the Board also controlled the route structure of each airline. The $\mathrm{CAB}$ permitted only a limited number of carriers to offer competing services in each major market, and one or two firms to serve the smaller markets. As existing

\footnotetext{
${ }^{6}$ See Moore $(1978)$ and Rose $(1985,1987)$ in the context of trucking regulation.
} 
markets expanded or new ones developed, the CAB often follow a compensatory policy of awarding more lucrative routes to weaker or less profitable firms (Caves, 1962, pp. 192-231).

Despite the regulation of routes and fares, individual airlines were free to vary the number of flights on their allotted routes. Industry analysts (e.g. Douglas and Miller (1974), DeVany (1975)) argued that airlines with parallel routes competed by offering more frequent flights, driving down marginal revenues per flight to the level of marginal cost. Perhaps the strongest evidence for this hypothesis took the form of low "load factors" in the regulated airline industry relative to the unregulated intrastate market. ${ }^{7}$ In the early 1970 s the CAB attempted to bolster industry profits by approving the formation of capacity-limiting agreements among the trunk airlines, although such agreements were only reached in a few markets (Graham and Kaplan, 1982, p. 13). Airline firms also competed on other dimensions of service, including the use of more modern aircraft and the provision of more comfortable seating. During the regulated era the average return on investment in the airline industry was relatively low (Bailey, Graham, and Kaplan, 1985, Table 1.2) suggesting that the overall degree of non-price competition was strong.

Although most observers believe that $\mathrm{CAB}$ regulatory policies created a favorable environment for raising airline workers' wages above competitive levels, the size of the effect is unclear. On one hand, the fact that fares were based on a markup over industry average costs suggests that airlines as a whole had limited incentives to resist wage increases. On the other hand, the extent of non-price competition and the fragmented collective bargaining structure of the industry suggest that even under $\mathrm{CAB}$ regulation individual firms had strong incentives to

\footnotetext{
${ }^{7}$ See Keeler (1981, pp. 60-66). The load factor is the average fraction of filled seats.
} 
resist wage increases. ${ }^{8}$ The lack of industry-wide bargaining meant that wage increases negotiated by one firm would not automatically raise industry average costs and regulated fares. Airlines' bargaining power was also bolstered by a strike insurance plan known as the Mutual Aid Pact. Under this agreement an airline grounded by a labor dispute received some of the extra revenues eamed by its competitors during the strike (see Unterberger and Koziara, 1977 and Cremieux, 1995). ${ }^{9}$ On balance, airline workers may have been less successful at capturing regulatory rents than their counterparts in other industries, such as over-the-road trucking.

\section{b. Deregulation}

Regulatory control of the airline industry was eliminated gradually over the 1975-81 period. Minimum pricing policies were relaxed in 1976 and 1977 and dropped altogether in late 1978. The CAB's authority over entry and route structures continued until 1981, although entry was substantially free by 1980 (Moore, 1986). Potential entrants responded almost immediately to the lifting of regulation: the number of certified airlines rose from 31 in 1977 to 93 in 1982 , and reached a peak of 106 firms in $1985 .^{10}$

Even more important than deregulation's effect on the number of airline firms was its effect on the structure of airline routes. In the early 1980s the airlines re-organized their routes

\footnotetext{
${ }^{8}$ Airline employees at different firms and in different occupation groups are represented by different unions, and historically bargained independently. See Kahn (1980) and Capelli and Harris (1985).

${ }^{9}$ The payments were often large: for example, in 1966 American Airlines eamed $\$ 48$ million in net income and paid \$29 million in Mutual Aid benefits (American Airlines, 1967).

${ }^{10}$ Airline firms have to be certified as "fit" to operate. Before 1978, certification was awarded by the $C A B$. With the demise of the $C A B$, certification fell to the Department of Transportation. A list certified airline firms is published annually in Air Transport.
} 
into "hub-and-spoke" networks. Such networks provide two key advantages. First, they raise productivity by creating a transfer station between smaller cities and allowing firms to consolidate long-distance travellers from many markets. ${ }^{11}$ Second, hubs create a strategic advantage in the highly competitive air travel market. By offering a wide range of flights at a hub, an airline creates a protected customer base that cannot be easily captured by a competitors' fare reductions. The increasing returns created by hubbing have led to a notable rise in the concentration of air travel business at many airports. The average fraction of passengers flying with the dominant carrier at each of the nations' 21 largest airports rose from 33 percent in 1977 to 51 percent in $1993 .^{12}$

A second innovation in the post-deregulation era is the expanded role of computer reservation systems. These systems -- airline-owned networks of computer terminals on travel agents' desks -- channel customer demand to the firm that owns the network and simultaneously gather market data needed to manage sophisticated pricing strategies. It is argued that American and United, which own the two dominant computer reservation systems, generate significantly higher revenue per passenger as a result of their control of travel agents' networks and through their yield management strategies (see Williams, 1994, chapter 2).

A comparison of the regulated and deregulated airline markets suggests that although the elimination of $\mathrm{CAB}$ control over routes and pricing policies eliminated the primary sources of

\footnotetext{
${ }^{11}$ Hub-and-spoke systems also allow for more efficient use of airline crews, and for consolidation of airline maintenance facilities.

${ }^{12}$ The 1977 figure is based on data in Williams (1994, Table 2.6). Comparable data for 1993 are taken from U.S. Department of Transport, 1994. The share of the dominant carrier rose at 16 airports and fell at 5 . Interestingly, all 5 airports with a decline in the dominant firm's share are on the east or west coast.
} 
rents in the airline industry, the emergence of hub-and-spoke route systems and the dominance of a few computer reservation systems have created other rent sources. Unlike the situation under $\mathrm{CAB}$ regulation, rents in the unregulated market arise from firm-specific factors. Thus employees at some firms may be able to maintain super-competitive wages in the unregulated industry, while wages at other firms may be driven to competitive levels. This reasoning suggests that deregulation might be expected to lead to a decline in average wages of airline workers and a simultaneous rise in the inter-firm dispersion in wages.

\section{Overview of the Industry}

To set the stage for an analysis of earnings trends, Table 1 presents some data on output and employment in the airline industry since deregulation. The left-hand columns of the table report two measures of output in the air travel sector: revenue passenger miles, and available seat miles. The latter is a measure of physical output, while the former is a measure of sales. The ratio of the two is the "load factor" or average fraction of filled seats, presented in column 3.

As shown by the growth rates at the bottom of the table, air travel has expanded rapidly in the past 30 years, with a somewhat slower rate of growth since $1978 .{ }^{13}$ Over the past 15 years revenue passenger miles grew faster than available seat-miles, reflecting a rise in average load factors (from 53.8 percent in 1960-77 to 60.7 percent in 1978-94). This upward shift is

\footnotetext{
${ }^{13}$ In fact, a simple prediction equation for revenue passenger miles that includes real GNP, a linear trend, and a post-1978 trend reveals a significantly slower rate of growth in revenue passenger miles after 1978 than in the $1960-77$ period. The estimated model is:

$$
\log (\mathrm{RPM})=\text { constant }+2.93 * \log (\mathrm{GNP})+0.003 * \text { trend }-0.018 * \text { Post }-1978 \text { trend. }
$$

The R-squared coefficient is 0.995 ; the t-statistic for the post-1978 trend coefficient is 3.4 .
} 
consistent with the hypothesis that high fares led to excessive scheduling competition and low load factors in the regulated industry. ${ }^{14}$

Column 4 of Table 1 shows the fraction of industry sales (i.e. revenue passenger miles) accounted for by the 11 original trunk airlines. Over the regulatory era this share was fairly stable at just over 90 percent. In the first few year of deregulation the incumbent trunks' market share dipped sharply, reaching a low of 77 percent in 1984. Starting in 1985, a series of acquisitions by the stronger incumbents led to a re-consolidation of the industry. These trends are illustrated in Figure 1, which shows the market shares of the three largest incumbents (American, Delta, and United); the other 8 original trunks (4 of which no longer survive); and the smaller incumbents and new entrants. The market share of the three leading survivors was fairly stable until 1985 . Thereafter, American's acquisition of Air California, Delta's acquisition of Western, and all three firms' rapid expansion into international markets led to steady rise in their combined industry share. ${ }^{15}$ By 1993 , the three largest firms accounted for 56 percent of total industry sales.

The next column of Table 1 reports average revenues per seat-mile eamed by the industry for combined domestic and international flights. Inflation-adjusted prices of passenger services have declined steadily in the past 30 years, with a slightly faster rate of decline since 1978 .

${ }^{14} \mathrm{As}$ predicted by the "quality competition" hypothesis, deregulation also led to lower quality via an increase in the number of seats per aircraft. For example, in the early 1980s, American increased seating by 11-12 percent on most of its fleet (American Airlines, 1980). Delta instituted similar changes in 1981-82 (Delta Airlines, 1982 and 1983).

${ }^{15}$ Other important mergers/acquisitions include Northwest's purchase of Republic in 1986, Transworld's purchase of Ozark in 1986, USAir's purchases of PSA and Peidmont, and the mid1980s merger of Texas International, New York Air, and Peoples Express into Continental. 
Price trends in the airline industry must be interpreted carefully, since technological changes have not necessarily occurred evenly over the past three decades. Moreover, changes in the relative prices of industry inputs may have contributed to differences in the rate of growth of output prices before and after deregulation. For example, real fuel costs rose sharply between 1968 and 1978, but fell between 1978 and $1994 .{ }^{16}$ Since fuel costs account for 10-20 percent of total cost in the industry, these trends would have been expected to generate a more rapid rate of decline in real seat-mile prices after 1978.

While most attention is usually devoted to the passenger travel component of the airline industry, the certified air transport sector also includes air cargo carriers. As shown in column 6 of Table 1, freight shipments (measured in ton-miles) have grown at a slightly slower pace than passenger miles since 1978. A key factor in the post-deregulatory growth of air cargo was the addition of Federal Express to the certified industry in $1986 .{ }^{17}$

Column 7 of Table 1 reports the rate of return on investment for airline firms as a whole. Airline profits are highly cyclical: the industry earned low returns in the early 1980 s and suffered unprecedented losses during the 1990-92 recession. Rates of return on investment in the airline industry have been relatively low since deregulation, averaging just 3.9 percent per year from 1979 to 1994 , versus 5.8 percent over the 1960 to 1978 period. Contrary to this realized experience, the stock market's reaction to the initial news of airline deregulation was mildly positive. Moore's analysis (1986, table 9) of stock returns suggests that investors anticipated

\footnotetext{
${ }^{16}$ Average jet fuel prices (in 1995 cents per gallon) were 46.5 cents in $1969,91.6$ cents in 1978 , and 74 cents in 1989.

${ }^{17}$ Prior to deregulation the industry included 3 "all cargo" airlines. The largest of these, Flying Tigers, was acquired by Federal Express.
} 
slightly higher future profits in the industry as a result of deregulation -- a very different situation than in trucking, for example, where news of deregulation had a negative effect on the value of incumbent firms (Rose, 1985).

Finally, columns 8 and 9 present data on airline industry employment and productivity. Industry employment was relatively stable in the decade before deregulation (growing at an average rate of only 0.5 percent per year) but has risen at a faster pace since 1978. Part of this faster growth is attributable to the addition of Federal Express to the industry in 1986. Even excluding Federal Express, however, employment in the rest of the industry grew at 2.0 percent per year between 1978 and 1994. The combination of faster employment growth and slower output growth after 1978 accounts for the relatively large drop in "productivity" growth (measured by growth in revenue passenger-miles per employee) following deregulation. ${ }^{18}$

While it may be tempting to conclude from this drop that deregulation lowered productivity growth, such an inference ignores the role of technological change in the airline industry. For example, prior to 1978, increasing aircraft size and the replacement of first generation jet aircraft led to significant productivity gains (see Kahn, 1980). ${ }^{19}$ Since 1978, aircraft size and other crude measures of aircraft technology have changed at a slower pace. A simple way to control for technological factors is to compare productivity growth in the U.S. airline industry relative to other countries. Between 1979 and 1994, passenger miles per

\footnotetext{
${ }^{18}$ Since Federal Express produces no passenger services, its employment has been excluded from overall employment count in the calculation of the productivity measure in column 11 of Table 1.

${ }^{19}$ First generation jet aircraft required three flight officers and relatively frequent maintenance. More recent aircraft have 2 instead of 3 or 4 engines, require only two flight officers, and have much longer service intervals (Kennet, 1988).
} 
employee grew by about 50 percent in the U.S. industry as a whole, with increases at individual firms ranging from just under 20 percent (at TWA and Northwest) to 103 percent (at United). ${ }^{20}$ By comparison, revenue passenger miles per employee grew by 16 percent at Air Canada, 66 percent at Air France, 90 percent at KLM, 95 percent at Lufthansa, 125 percent at Japan Airlines, and 136 percent at British Airways. These data suggest that the U.S. carriers had comparable productivity growth to other major international firms over the past 15 years, and that deregulation probably did not slow the relative growth of productivity. ${ }^{21}$

The industry-wide data in Table 1 and Figure 1 point to three important factors for understanding the labor market impacts of deregulation. First, airline industry output and employment have continued to grow since deregulation. Employment growth has been particularly strong, averaging 2 percent per year since 1978. Second, the airline industry is extremely cyclical. The 1982 and 1990 recessions both resulted in slow output growth and employment cuts. Third, while deregulation has led to a proliferation of airline firms, the industry is still dominated by a few large carriers. In fact, over 50 percent of industry output is now produced by the three largest firms in the industry, and the 7 surviving incumbent trunk airlines together account for over 85 percent of industry output. Moreover, sales in individual airline markets are now more highly concentrated than under regulation.

\footnotetext{
${ }^{20}$ Data on employment and output of most major airlines in the world are available in annual reports of the International Air Transport Association (IATA). One explanation for firm-specific differences in productivity growth is average flight length, which expanded more rapidly for United than for TWA or Northwest.

${ }^{21}$ Caves, Christensen, Trethaway, and Windle (1987) compare international airlines in the early 1980s and conclude that deregulation boosted relative productivity growth in the U.S. industry.
} 


\section{Changes in Earnings for Airline Workers}

\section{a. Overview}

Table 2 presents an overview of eamings trends in the airline industry from 1975 to 1994. The average weekly earnings data in this table are derived from three sources: firm-level average earnings data (reported in the FAA Statistical Handbook of Aviation and ATA's Air Transport); establishment-level data collected by the BLS Industry Wage Surveys; and individual wage data collected by the Current Population Survey (CPS). For comparative purposes, the fourth column of the table shows average weekly eamings for non-supervisory workers in the overall economy. The earnings data are reported in 1995 dollars, using the Consumer Price Index as a deflator.

The firm-based earnings series in column 1 suggests that average real wages in the airline industry were relatively stable from 1975 to 1983 , fell about 11 percent between 1983 and 1991 , and have been roughly constant since then. Industry Wage Survey (IWS) data are only available for 1975,1980 , and 1984 , but confirm the relative stability of real wages between 1975 and 1984. ${ }^{22}$ Other firm-based data series, such as the ones analyzed by Cremieux (1996) and Hirsch and Macpherson (1994a, Table 10), are consistent with these patterns, and show a 10-13 percent decline in average wages in the certified airline industry between the mid-1970s and the early 1990s.

\footnotetext{
${ }^{22}$ The published IWS summaries do not include wages for all occupations, and do not provide an overall industry average wage. I used the reported wage and employment data by occupation to construct a weighted average industry wage for each year.
} 
The data in column 3 are taken from Hirsch and Macpherson (1994a), and are derived from individual micro data collected in the monthly Current Population Survey (CPS). ${ }^{23}$ The scope of the air transport industry in the CPS (and in the Census data files analyzed below) is somewhat broader than the certified airlines included in the data in columns 1 and 2 . Specifically, the CPS and Census industry classification also includes local air taxis and charters, as well as airport service establishments. I estimate that the certified industry accounted for about 65 percent of all workers in the Census air transport industry in 1980 and about 70 percent in 1990. This broader industry definition creates some slippage in drawing inferences about the certified air transport sector from CPS or Census data.

Whether because of the broader industry definition or for other reasons, average weekly earnings of airline workers measured in the CPS are 15-18 percent lower than average weekly earnings measured from firm-level data. Nevertheless, the CPS-based wage data show a similar pattern over time. In particular, the wage series in column 3 shows roughly constant real wages until the early 1980s, followed by a modest (10 percent) decline.

Interestingly, the magnitude of the post-deregulation decline in real wages for airline workers (from either firm or individual data sources) is very similar to the decline in economywide average wages from 1979 to 1994 registered by the wage series in column 4 of Table 2 . This earnings series, which is derived from payroll surveys, shows a 12 percent fall in average wages of all non-supervisory workers in the U.S. labor market, versus the 12-14 percent decline for airline workers in columns 1-2 and the 10 percent decline for airline workers in column 3 .

\footnotetext{
${ }^{23}$ The data are derived from questions asked about an individual's weekly or hourly earnings on his or her main job as of the CPS survey week. See Card (1989) for an extensive discussion of alternative earnings measures in the CPS.
} 
The similarity of earmings trends in the airline industry and the overall economy is potentially surprising. It should be noted, however, that most other aggregate wage series show a different trend than the payroll-based series in column 4. Indeed, most series show roughly constant aggregate real wages between 1979 and the early 1990s, implying a decrease in airline workers' relative wages after deregulation. ${ }^{24}$ It is also worth noting that the dramatic changes in the structure of wages that occurred throughout the economy over the 1980 s might have been expected to lead to some change in airline relative wages even in the absence of deregulation, since airline workers are more educated and more likely to be male than other workers. In order to make a reliable assessment of relative earnings trends it is necessary to use a data set that provides comparable earnings information for airline and non-airline workers, and also includes data on education, age, gender, and other factors that affect the structure of wages.

\section{b. Micro Data on Relative Eamings}

Previous studies of the effect of deregulation on earnings in the airline industry have relied on Current Population Survey data (e.g., Card, 1989, Hirsch and Macpherson, 1994a). A major limitation of the CPS is the relatively small number of airline workers in the sample. Since the airline industry accounts for only 0.7 percent of all U.S. workers, a typical monthly CPS sample includes only 350-400 airline workers. An alternative source of individual micro data that provides far larger sample sizes is the decennial Census. In the Census, individuals are asked their total annual earnings for the previous year, and their weeks of work and usual weekly hours. These responses can be combined to construct average weekly or hourly earnings over

\footnotetext{
${ }^{24}$ See BLS (1994, pp. 50-53).
} 
the previous year. Although retrospective earnings and hours data are conceptually less attractive than the point-in-time wage measures available from the monthly CPS files, a comparison by Card and Lemieux (1996, Table 9) suggests that the trends in two data series have been quite similar over the 1980s.

Table 3 presents some descriptive statistics on the samples of airline workers and nonairline workers available from the 5-percent public use files of the 1980 and 1990 Censuses. In drawing these samples I included all employees in the airline industry with positive (nonallocated) earnings, and 5 percent of workers in all other industries (see the Data Appendix). To measure any recent (post-1989) trends, I atso constructed a pooled sample of workers from the March 1994 and 1995 Current Population Surveys. (The March CPS includes retrospective earnings and hours questions very similar to those in the decennial censuses). Note that the two March CPS samples together contain only 789 airline employees, compared with 20-30 thousand airline workers in the Census files.

The demographic characteristics in rows $2-5$ of Table 3 reveal that airline workers are more highly-educated than those in other industries. The gap of about 0.5 years of schooling has not changed appreciably since 1980 . Airline workers are also disproportionately male and much more likely to be veterans of the armed forces. Again, the relative fractions of women and veterans in the airline industry have not changed much since 1980 . In contrast to the differences in education, gender, and veteran status, the airline industry includes about the same fraction of nonwhites as the overall labor force.

Rows 6-11 of Table 3 present a variety of information on weekly and hourly earnings in 1979,1989 , and 1993-94. As suggested by the data in Table 2, airline workers earn significantly 
higher average wages than employees in most other industries. For example, in 1979 the ratio of mean weekly wages of airline workers to non-airline workers was 1.52 , while the gap in mean log hourly wages was 0.46 . The relative distributions of airline and non-airline workers in 1979 and 1989 are illustrated in Figure 2. In 1979 the wage distribution of airline workers appears to be both shifted to the right and more compressed than the wage distribution of other workers. In 1989 , the differences between the two distributions appear smaller, although the airline wage distribution is still shifted to the right. Despite these visual impressions, conventional measures yield ambiguous conclusions about the relative inequality of wages in the airline industry. Using the standard deviation of log hourly wages as a benchmark, airline wages were more disperse than non-airline wages in 1979; using the interquartile range as an index, airline wages were less disperse.

The data in Table 3 yield somewhat different conclusions about the trend in aggregate real wages than the BLS payroll series reported in Table 2. In particular, real hourly wages in the non-airline sector show only a small drop between 1979 and 1989 in the Census data, compared to the 10 percent decline in column 4 of Table $2 .{ }^{25}$ Real wage trends in both the airline and nonairline sectors are also somewhat sensitive to whether wages are measured by the hour or by the week. These differences are explored in greater detail below.

Table 4 presents a series of estimated regression models that measure trends in the relative wages of airline workers over the past two decades. These models regress the log of average hourly earnings for an individual on an indicator for employment in the airline industry, or on

\footnotetext{
${ }^{25}$ Aggregate wage trends in the decennial Census are therefore more in line with other data sources, such as the March CPS and unemployment insurance tax records -- see BLS (1994).
} 
a set of interactions of an airline industry dummy with dummies for specific occupation groups. The table presents models with no other control variables (in the odd-number columns) and models with a standard set of individual-level control variables (in the even-numbered columns).

Examination of the estimated coefficients in Table 4 leads to three basic conclusions. First, the addition of conventional "human capital" control variables lowers the estimated airline wage differential by 10-14 percent, with a slightly larger adjustment in 1979 than in later years. On average, differences in education, location, gender, and experience account for about onethird of the gross wage advantage of airline workers. At the occupation level, the adjustment is particularly large for pilots (who are mainly males, have high education, and tend to have considerable experience) and is negligible for flight attendants. Second, the estimated hourly wage premium for working in the airline industry is relatively large for pilots and flight attendants (40-70 percent), and more modest for aircraft mechanics and "non-specialized" occupations (10-20 percent). As shown below, this is partly an artifact of the low hours worked by airline flight personnel. Third, the time-series patterns of the raw and adjusted wage differentials show about a 10-15 percent decline in the airline industry premium between 1979 and 1989, with little or no change from 1989 to 1993-94. For pilots and flight attendants the relative declines are roughly similar using unadjusted or adjusted earnings. For mechanics and for "non-specialized" occupations the declines in unadjusted wages are larger than the declines in adjusted wages. The discrepancy is especially notable for mechanics: mean log wages of airline mechanics declined 13 percent from 1979 to 1989 , but their adjusted wages were virtually constant. 


\section{c. Changes in Wage Differentials By Occupation}

In light of the findings in Table 4 it is interesting to look more carefully at the effects of deregulation on different occupation groups. It is also important to check the robustness of any conclusions to the use of an hourly versus a weekly wage. Although the hourly wage is an appropriate measure of pay for most occupation groups, a weekly wage is arguably better for pilots and flight attendants. FAA regulations restrict pilots to a maximum of 85 flying hours per month, and many union contracts limit pilot hours even further. Similarly, most flight attendant contracts specify overtime pay for hours in excess of 65 per month. Given these institutional features, weekly earnings may be a better measure of the relative return to full-time employment in the airline industry.

Table 5 presents estimated airline industry differentials in hourly and weekly wages for specific occupation groups in 1979, along with the changes in the corresponding differentials from 1979 to $1989 .{ }^{26}$ The differentials are derived from regression models that include the same covariates used in the even-numbered columns of Table 4. The results in row 1 compare the evolution of the airline industry wage differential in hourly and weekly earnings. In 1979, the airline wage premium was slightly larger for hourly than weekly wages, while the reverse was true in 1989 . Thus the decline in the hourly wage premium is larger than the decline in the weekly wage premium. Examination of the results in rows 2 and 3 reveals that the discrepancy between hourly and weekly earnings is relatively large for pilots and flight attendants. For other

\footnotetext{
${ }^{26}$ For simplicity I have not presented any information on wage developments in the early 1990s. As suggested by the patterns in Table 4, changes in airline industry wage premiums from 1989 to $1993 / 94$ are generally small and unsystematic.
} 
occupations there is little difference in the airline differential for weekly or hourly earnings, and to save space I present only the hourly results for these groups.

Further analysis of the hours data for pilots and flight attendants shows that both groups reported a substantial rise in hours per week from 1979 to 1989. Pilots reported an average of 41.8 hours per week in 1989, versus 37.0 hours per week in 1979 -- a 13 percent increase. Flight attendants reported 35.7 hours per week in 1989 versus 32.3 hours in 1979 -- an 11 percent increase. As a mechanical matter, these rises in hours "explain" the discrepancies between the relative changes in hourly and weekly wages for flying personnel over the 1980 s. Whether this apparent rise in hours is due to deregulation or to an inherent weakness in the Census data is less certain. The sample sizes of pilots and flight attendants in the Census files are reasonably large, ruling out a sampling error explanation. ${ }^{27}$ Nevertheless, given actual work practices in the industry, the average weekly hours reports for pilots and flight attendants in both 1979 and 1989 seem too high. For example, a pilot flying 85 hours per month works an average of just under 20 hours per week. In 1979, however, only 29 percent of pilots reported working less than 30 hours per week; in 1989 this fraction was only 18 percent. The Census data show a parallel decline in the fraction of flight attendants who report working less than 30 hours per week (from 43 to 31 percent). Given the probable inaccuracy of the hours data, some caution is required in interpreting the hourly wages for pilots and flight attendants.

${ }^{27}$ The 1979 file contains 2540 pilots and 2649 flight attendants. The 1989 file contains 3610 pilots and 3646 flight attendants. These counts are consistent with ATA data for employment in the certified industry, assuming that virtually all flight attendants and about 70-75 percent of pilots work in the certified industry. The sampling error of measured average hours per week is about 0.25 hours for both pilots and flight attendants in both years. 
With this caveat in mind, the results in Table 5 suggest that most occupation groups in the airline industry experienced a relative decline in eamings over the 1980 s. The largest declines are measured for flight attendants (11-18 percent) and the smallest for mechanics (no change). Perhaps surprisingly, the decline in the airline industry wage premium for workers in non-specialized occupations is similar in magnitude to the declines for pilots and flight attendants. Moreover, there is no apparent connection between the size of the post-deregulation decline in the airline industry wage effect and the magnitude of the effect in 1979.

An alternative to measuring the airline wage premium by occupation is to classify workers by education. As shown by the results in rows 6 and 7 of Table 5, more and less educated workers earned fairly similar wage premiums for working in the airline industry in 1979 . Over the 1980s, the premium for more educated workers fell slightly faster (10 versus 6 percentage points). Again, however, one is struck by the similarity rather than the difference in the trend across education groups.

Traditionally, economists have pointed to trade unions as the mechanism by which workers appropriate rents in regulated industries. Thus it is interesting to examine postderegulatory earnings trends for occupations with negligible union coverage. Two such groups are managers and secretaries. Since both occupations are broadly represented outside the airline industry, it is possible to estimate occupation-specific wage equations that include an airline industry dummy. The results of this exercise, reported in rows 8 and 9 of Table 5 , suggest that prior to deregulation managers earned about a 14 percent wage advantage for working in the airline industry, while secretaries eamed about an 18 percent premium. These are the lowest airline wage differentials reported in the table for 1979 , and could be interpreted as evidence that 
non-unionized employees captured few of the rents from regulation. Nevertheless, both groups experienced sizeable declines in the airline wage premium between 1979 and 1989 . Indeed, the decline in relative wages of managers in the airline industry is larger than the decline for workers as a whole. Assuming that the change in the airline premium from 1979 to 1989 measures the size of regulatory rents, the findings in Table 5 suggest that nonunion occupations like managers and secretaries eamed roughly similar regulatory rent premiums as other highly unionized occupations.

\section{d. Changes in Wage Dispersion}

If wages are linked to firm-specific rents, and the inter-firm dispersion in potential rents has risen following deregulation, then one might expect deregulation to increase wage inequality. Table 6 presents some very simple evidence on this issue, using the 1980 and 1990 Census micro data on hourly and weekly wages. Throughout the table, earnings dispersion is measured by the standard deviation of log hourly or weekly wages. As noted in Table 3, different inequality indexes give slightly different impressions of the patterns of earnings dispersions in the airline industry: this should be kept in mind in interpreting the results in Table 6 .

The first two rows summarize trends in wage inequality outside the airline industry. Although much attention has focused on the rise in wage dispersion over the 1980s (e.g. Levy and Murmane, 1992) the increase in earnings inequality measured in the decennial census data is relatively modest. Part of the reason for this is the pooling of male and female workers: the 10 percentage point closing of the male-female wage gap over the 1980s (Blau and Kahn, 1995) lessened a major source of overall wage inequality that is ignored in typical studies of male wage 
inequality. Based on the census data, the standard deviation of hourly wages outside the airline sector rose about 4 percent over the 1980s, while the standard deviation of weekly wages rose 7 percent.

The dispersion of hourly wages in the airline sector rose by slightly less than in other sectors ( 3 percent) while the dispersion of weekly wages rose by more (13 percent). Within occupation categories the patterns are broadly similar: weekly wages show a larger increase in inequality than hourly wages; and for most occupation groups the standard deviation of log weekly wages rose by as much or only slightly more than elsewhere in the labor market. Based on these results, there is only limited support for the hypothesis that deregulation led to a rise in earnings inequality in the airline industry.

\section{e. Collective Bargaining Contract Data}

Under regulation the airline industry was relatively highly unionized (see Kahn, 1980 for a brief history). Prior to deregulation the pilots at all 11 incumbent trunk airlines were represented by unions, as were the flight attendants and aircraft mechanics at all but one firm (Delta). In the deregulated era, despite the entry of non-union airlines and management efforts to de-unionize at least one major carrier, the fraction of airline industry employees covered by union contracts has remained stable at around 40 percent (Hirsch and Macpherson, 1994b, Tables $12 \mathrm{a}$ and $12 \mathrm{c})$. Contrary to trends in the rest of the economy, the propensity of airline workers for unions seems remarkably robust. For example, pilots and flight attendants at Continental recently re-established union coverage, while representation elections continue to be fought and won at many new entrant firms. 
In light of the importance of collective bargaining in the airline industry, it is interesting to examine contractual wages for the three major craft groups in the industry (pilots, flight attendants, mechanics) and compare trends in the level and inequality of contractual wages with the patterns estimated using individual micro data. A major limitation of contract data is the lack of information on the number of workers in each job category. In the absence of this information I have attempted to construct earnings indexes for pilots, flight attendants, and mechanics assuming a fixed job description and a fixed level of seniority.

The choice of job descriptions and seniority levels is arbitrary, but affects the accuracy of the index to the extent that wage differentials for different jobs or seniority levels change over time, or that the distribution of workers across jobs or seniority levels changes over time. Unfortunately, both factors have changed during the past decade. The emergence of two-tier labor contracts in the mid-1980s led to a major rift in wages between more and less senior workers. ${ }^{28}$ Although many firms have eliminated their two-tier systems, recent contracts retain a much steeper seniority profile than before. With respect to the second factor, the age structure of one important group -- flight attendants -- has changed significantly since deregulation (see below). These changes call for careful interpretation of earnings indexes based on a fixed level of seniority.

Tables $7 \mathrm{a}-7 \mathrm{c}$ provide a summary of average wage rates for pilots, flight attendants, and mechanics at the major incumbent airlines in 1980, 1987, and early 1995 . The tables also show

\footnotetext{
${ }^{28}$ Two-tier contracts contain separate wage schedules for individuals hired before a certain date, and those hired afterward. See Capelli (1987) for a history and analysis of these contracts in the airline industry as of 1986 . Two-tier pay schedules are not restricted to unionized firms. Delta Airlines instituted a two-tier pay arrangement for its nonunion workers in 1984, but abandoned the plan in August 1988.
} 
the number of workers at each firm as of year-end, an employment-weighted average wage (in current and 1995 dollars), and the coefficient of variation of wages across the incumbent firms.

Table 7a reports hourly wage rates for the captain of a Boeing 727 aircraft with 10 years of seniority. ${ }^{29}$ The contract data show a 13 percent decline in average real wages of captains at the incumbent trunk airlines since deregulation, with all of the decline occurring between 1980 and 1987. There was also a sharp increase in inter-firm wage dispersion: the coefficient of variation of hourly wages rose from 4.3 percent in 1980 to 25 percent in 1987 . The increase in dispersion in the early 1980 s was attributable to wage cuts or freezes at five financially troubled airlines: Braniff, Continental, Eastern, Pan Am, and Transworld. ${ }^{30}$ By the early 1990s three of these firms had failed, while Continental pilots had re-unionized and negotiated a modest pay increase relative to rates at the industry leaders (American, Delta, and United). These factors, along with the relative rise in employment at the 3 leading firms, led to some narrowing of interfirm dispersion from 1987 to 1995 . On net, however, the contract data show a widening of inequality for unionized pilots after deregulation.

Union contract wage scales for flight attendants are presented in Table $7 \mathrm{~b}$. By the mid1980s, most incumbents had negotiated two-tier pay schedules for flight attendants, with a typical 30 percent wage reduction for newly hired workers. I have shown wages for both the high and low tiers in the table -- in each case, assuming 5 years of seniority. The introduction of two tier

${ }^{29}$ Although some pilot contracts set lower wages for newly hired workers, all of the contracts guarantee wage equality for captains. Thus, there is no effect of two-tiered wage provisions on captains' wages, although there is clearly some effect on wages for first and second officers (see Walsh (1988), Table 3).

${ }^{30}$ Continental abrogated its union contracts in 1985 . The 1987 wage rates for Continental employees reported in Tables 7a-7c are from company employment policy statements. 
schedules makes it difficult to construct an average wage across firms: I have used a simple average of the two scales in constructing the industry average wage and coefficient of variation.

The contract data for flight attendants show a large (40 percent) fall in average real wage rates from 1980 to 1995 , with a somewhat bigger decline after 1987 than before. An important factor in interpreting theses trends, however, is the role of seniority. The decline in wages for flight attendants with 5 years of seniority overstates the decline in wages for a representative flight attendant for two reasons. First, the average age of flight attendants increased by 7 years between 1979 and 1995, implying a substantial upward shift in seniority. ${ }^{31}$ Second, as firms have moved to eliminate permanent two-tier pay schedules, they have increased the slope of the seniority wage gradient for flight attendants. ${ }^{32}$ Even allowing for these factors, however, the contract data suggest that flight attendant real wages have fallen since deregulation. The trend in wage dispersion is also positive, although the rise in inter-firm wage differentials is smaller than for pilots.

Finally, Table $7 \mathrm{c}$ reports union contract wage rates for aircraft mechanics. Traditionally, mechanics' contracts contained relatively limited seniority provisions, with rates reaching a maximum after only 2 years. More recently the airlines have negotiated extended seniority

${ }^{31}$ In 1979 the average age of flight attendants was 30.4 years -- far below the average age of 36.2 for the workforce as a whole. The pooled March 1994/95 CPS files show an average age of $\mathbf{3 7 . 7}$ for flight attendants versus a labor force average age of 38.0 .

${ }^{32}$ For example, the USAir-flight attendant contracts in the late 1970 s and early 1980 s increased wages by about 40 percent in the first 5 years of seniority, and a further 14 percent in the next 5. The 1986 contract introduced a second-tier pay schedule for new hires, with $25-30$ percent lower pay rates. The 1988 contract eliminated the second tier, but effectively retained the lower tier pay rate for low-seniority workers, so that pay rates rose only 17 percent in the first 5 years of seniority but then increased 60 percent in the next 5 years. 
schedules that lowered wages by $20-30$ percent in the first 4 or 5 years of employment. Compared to pilots and flight attendants, however, the mechanics' seniority schedules are still relatively compressed. ${ }^{33}$ Thus Table $7 \mathrm{c}$ presents wage rates for mechanics at the top of the seniority scale.

Adjusted for inflation, the average union contract wage for mechanics shows little change between 1980 and 1987 and then a roughly 10 percent drop from 1987 to 1995 . The trend in wage dispersion is similar to the trend for pilots, although dampened, with a rise from 1980 to 1987 and then a fall from 1987 to 1995 . Apart from Continental, inter-firm wage differentials for mechanics were very small in $1995 . .^{34}$

How do the trends in collective bargaining pay scales mesh with the findings in Tables 4-6 based on Census and CPS microdata? For pilots, the microdata show a modest decline in relative wages while the contract data show a 10 percent decline in real wage levels. Assuming that real wage rates of non-airline workers were roughly constant, the trends in pilot wages are therefore roughly consistent across the two sources. The trends in wage inequality are not, however, since the Census data show little increase in inequality, while the contract data show a sharp rise in inter-firm inequality. Part of the discrepancy may be attributable to problems of measurement error in the Census and CPS earnings and hours data. Part may also be due to the fact that pilots hold a very diverse set of jobs in the broadly defined airline industry -- from

\footnotetext{
${ }^{33}$ Furthermore, the extended seniority schedules have not always been binding. For example, the September 1985 mechanics' agreement at American offered accelerated seniority to workers on the extended seniority schedule.

${ }^{34}$ As of 1995 , Continental mechanics are still nonunion. Delta mechanics are also nonunion, although their pay scales are comparable to those at American.
} 
flying single-engine air taxis to large commercial jets. Relative to the overall distribution of pay across all these jobs, the dispersion in pay for captains in the certified airlines is small.

For flight attendants, the microdata show a 10-17 percent decline in relative wages and a significant increase in wage inequality, while the contract data show a 40 percent decline in real wage levels and a rise in both inter-firm and within-firm wage inequality. As discussed above, the decline in the real wage rate at a fixed point in the seniority scale for flight attendants clearly overstates the decline in real wages for a representative worker. Thus, the trends in the levels of real wages in the contract data and micro data may be roughly consistent. It is difficult to assess the effects of two-tier pay schedules and steepened seniority schedules on the level of wage inequality for flight attendants. Superficially, the inequality trends in the contract and micro data are broadly compatible.

Finally, Census and CPS microdata for mechanics show roughly constant relative wages since deregulation and a modest rise in wage inequality, while the contract data show an 11 percent decline in real wage levels and a small increase in inter-firm inequality. Although these trends may seem inconsistent, recall that the Census microdata actually show falling average wage rates for mechanics relative to all non-airline workers. ${ }^{35}$ After taking account of age, education, gender, and other observable factors, however, mechanics' relative wages were constant between 1979 and 1989. The key adjustment factors are education and gender: airline mechanics are over 90 percent male and have lower-than-average education. Adjusting for the

\footnotetext{
${ }^{35}$ According to the data in Table 4, the unadjusted airline mechanic wage differential falls from 0.473 to 0.347 from 1979 to 1989 . The adjusted differential, however, is 0.216 in 179 and 0.224 in 1989.
} 
relative pay declines of men and less-educated workers over the 1980s, airline mechanics kept pace with similar workers in other sectors. Thus, the earnings trends for mechanics in the union contracts and microdata are broadly compatible.

\section{An Analysis of Job Losers, 1984-94.}

Census/CPS microdata and union contract data both suggest that earnings in the airline industry declined relative to earnings outside the industry during the 1980s. A simple interpretation of this fact is that airline wages contained a regulatory rent premium that was gradually eliminated after deregulation. Another way to measure the regulatory wage premium among airline workers is to compare the earnings changes of individuals who lost jobs in the airline industry during the 1980 s with the earnings changes of other job-losers. ${ }^{36}$ One might expect former airline workers to experience above-average wage losses if their pre-displacement earnings included a rent premium. Indeed, the difference in wage changes between former airline workers and other workers is one potential estimate of the regulatory rent premium. ${ }^{37}$ To the extent that job-losers from other sectors also earned non-competitive wage premia, however, the difference in wage changes between former airline workers and other job-losers may understate the size of regulatory rents in the airline sector.

\footnotetext{
${ }^{36} \mathrm{Hirsch}$ and Macpherson (1994a, Table 7) analyze year-to-year wage changes using a sample of individuals who are interviewed in consecutive years in the CPS, pooled with a sample of individuals who report both their wage for the previous year and the wage on their current job as of the March CPS survey.

${ }^{37}$ Displaced workers are typically a non-random sample of workers from a given sector. Thus any comparison of wage changes for job-losers from different sectors implicitly assumes that the degree of selectivity bias in the observed distribution of wage changes is similar for workers from the different sectors.
} 
The Displaced Worker Surveys (DWS) conducted by the Census Bureau in January 1984, 1986, 1988, 1990, 1992, and February 1994 asked individuals if they had lost a job in the previous 5 years ( 3 years in the 1994 survey), and if so, their earnings on the old job and their current job. ${ }^{38}$ Table 8 presents some descriptive statistics on the set of job losers interviewed in the combined displaced worker surveys, and on the subset of these individuals displaced from jobs in the airline industry. Each of the DWS surveys includes 7,000-9,000 job losers. Nevertheless, the total number of former airline workers is only 342 ( 0.7 percent of the sample, or about the same fraction as airline workers comprise of the overall workforce). The relatively low number of airline job losers reflects the small size of the airline industry and the fact that industry employment has actually expanded at about the same rate as the overall labor force since deregulation.

The characteristics of workers displaced from the airline industry present an interesting contrast with other displaced workers and with the stock of workers employed in the industry. For example, former airline workers are better-educated and more likely to be men than other displaced workers: both features are consistent with the data for the currently employed airline workers in the 1980 or 1990 Census (see Table 3). The ratio of mean weekly earnings of exairline employees to the mean earnings of all displaced workers is 1.29 ; the ratio of the corresponding medians is $\mathbf{1 . 4 5}$. This $30-45$ percent wage premium is slightly less than the crosssectional wage premium for airline workers in 1979 (45-60 percent according to the data in Tables 3-4) but closer to the cross-sectional premium in 1989 (roughly 30-40 percent). As shown

\footnotetext{
${ }^{38}$ The DWS surveys have been used by many previous authors -- see Farber (1996) for a recent analysis.
} 
in the third column of the table, the general nature of the airline industry group is similar when pilots are excluded, although pilots tend to have higher education and higher wages than other workers.

Relative to other displaced workers, the post-displacement experiences of former airline workers show some interesting differences and similarities. Airline and non-airline workers report comparable unemployment experiences after a job loss, but airline workers are more likely to be re-employed at the survey date and more likely to have moved geographically after displacement. They are also more likely to return to jobs in their pre-displacement industry: at the survey date 39 percent of airline workers were re-employed in the airline industry versus an average industry re-employment rate of 25 percent. Despite these differences, the mean wage change conditional on re-employment is very similar for former airline workers and other displaced workers (see row 5f). Moreover, the fractions of ex-airline workers who experienced bigger than 10 percent wage losses or gains are similar to the fractions for other displaced workers (rows 5g, 5h).

Table 9 presents a series of estimated regression models that attempt to measure any airline-specific effect in the pre- to post-displacement wage change. With one exception (explained below) the models are fit to the subsample of individuals who report valid predisplacement and post-displacement wages. The model in column 1 includes only a dummy variable for pre-displacement jobs in the airline industry. The model in column 2 adds a set of standard covariates, while the model in column 3 excludes pilots. Finally, the models in columns 4-6 examine the 25 th, 50th, and 75 th percentiles of the wage change distribution, respectively, using a standard quantile regression technique. 
The estimates in columns 1-6 of Table 9 imply that workers displaced from the airline industry experienced very similar wage changes to workers displaced from other industries. Although the standard errors are relatively large, the point estimates are numerically small and center on zero. The estimates rule out an airline-specific effect any larger than $+/-10$ percent, both at the mean, and at the median, 25th percentile, and 75 th percentile of the wage change distribution.

One difficulty with drawing inferences from the models in columns $1-6$ is that the underlying sample excludes individuals who were still unemployed as of the displaced worker survey date. Since airline workers have higher re-employment rates than other workers, it is possible that the estimated airline effect on accepted wage offers is a biased estimate of the airline effect on potential wage opportunities. To explore this possibility, I assigned all non-workers at the time of the survey a log wage change of -1 . I then estimated a quantile regression for the 75th percentile of wage changes. Since the 75 th percentile of log wage changes for this augmented sample is above -1 , this is equivalent to assuming that displaced workers who were unemployed at the survey date would have experienced a wage change below the 75th percentile if they had accepted their best job opportunity.

Estimates of this model are reported in column 7 of Table 9. Comparisons of the coefficient estimates for the control variables in columns 2-6 with those in column 7 show some interesting differences. For example, the nonwhite effect is negligible in the conditional models in columns 2-6 but large and negative in the unconditional model in column 7, implying that nonwhite displaced workers have lower re-employment rates than whites, but similar wage changes conditional on re-employment. The estimated airline industry effect in column 7 is 
relatively imprecise but positive. Even accounting for the likelihood of re-employment, there is clearly no evidence that airline workers experienced bigger wage losses than other displaced worker.

A second issue in interpreting the results in Table 9 is the timing of job losses in the sample. The 1984-1994 Displaced Worker Surveys include individuals who lost jobs between 1979 and 1994. If the regulatory rents earned by airline workers eroded over the 1980s, then the wages of airline job losers from the later part of the sample period may have already fallen prior to their displacement. In this case, the relative wage changes of ex-airline workers measured in Table 9 may understate the average regulatory wage premiums earned prior to deregulation. To check this possibility, I re- estimated the models including only job losers from 1979 to 1985 . Contrary to the hypothesis of bigger relative wage losses for airline workers in the early 1980s, the estimates show the opposite pattern: the estimated airline job effects are slightly more positive than those reported in Table 9 (with slightly larger standard errors).

As noted in Table 8, one of the interesting differences between job losers from the airline industry and other displaced workers is the relatively lower fraction of airline workers who changed industries after their displacement. Previous studies of displaced workers have found that industry changers suffer bigger wages losses than non-changers. ${ }^{39}$ Thus the lower rate of industry switching among airline job losers may account for their relatively favorable post-displacement earnings experiences. Table 10 presents a series of regression models that compare the pre- to post-displacement wage changes of industry stayers and industry switchers. These models include a dummy variable for industry switchers, a dummy variable indicating a

\footnotetext{
${ }^{39}$ See e.g. Neal (1995) and Parent (1995).
} 
pre-displacement job in the airline sector, and the interaction of the two effects. To aid in interpreting the estimates the rows 4 and 5 of the table show the implied wage changes of airline job losers who were re-employed in the airline industry, and those who were not, relative to an average displaced worker from other sectors.

The estimates in Table 10 confirm that on average, displaced workers who change industries have significantly larger wage losses (i.e., more negative wage changes) than industry stayers. For displaced workers from the airline sector, however, there are no significant differences between the wage changes of industry stayers and industry movers. Both groups have larger wage losses than industry stayers displaced from other industries but smaller wage losses than industry switchers displaced from other industries. ${ }^{40}$ Although the coefficient estimates are relatively imprecise, they suggest that the industry-specific component of pre-displacement wages for ex-airline workers is actually smaller than the industry-specific component for most other displaced workers.

A simple interpretation of the patterns of relative wage changes among airline job losers and other displaced workers is that the pre-displacement "rents" earned by airline workers were of comparable magnitude to the "rents" (or returns to industry-specific human capital) earned by displaced workers from other industries. Thus the patterns of relative wage changes for job losers from the Displaced Worker Surveys reinforce the conclusion from Census microdata and union contract data that airline workers earned relatively modest industry-specific wage premiums in the regulated era.

\footnotetext{
${ }^{40}$ I re-estimated the models in Table 10 using only job losers from 1979 to 1985 and found very similar results.
} 


\section{Summary and Conclusions}

Airline workers' relative wages have declined by about 10 percent since 1980 . Assuming that the deregulated industry can be taken as a competitive benchmark, this shift implies that airline workers received about a 10 percent wage premium under regulation. There are several explanations for the moderate size of this rent premium. Non-price competition in the regulated airline industry was relatively strong, and may have dissipated a substantial fraction of potential regulatory rents. Moreover, airline unions never succeeded in "taking wages out of competition" through industry-wide bargaining. Relative to employees in other regulated industries, airline workers may have been less successful in capturing a share of the rents created by regulation.

An alternative explanation for the modest decline in airline wages since 1980 is that employees at many firms are still earning rents. Even in the deregulated marketplace the larger airline firms have been able to retain a degree of market power through hub-and-spoke route networks and the strategic control of computer reservation systems. Indeed, the airline industry is more concentrated now than in the decades prior to deregulation. Evidence from the experiences of job losers, however, suggests that airline workers do not suffer larger wage losses following a job displacement that job-losers from other industries. Moreover, airline job-losers who are change industries fare about as well as those who are re-employed in the airline industry. Taken together with the cross-sectional evidence, these patterns suggest that any regulatory or non-competitive rents eamed by airline workers are relatively modest, and comparable to the wage premiums earned in many other sectors.

Perhaps more surprising than the size of the post-deregulation wage decline is its uniformity across different occupation groups. Wages declined by about as much for highly 
unionized industry-specific occupations like pilots and flight attendants as for nonunion occupations like managers and secretaries. The apparent similarity of the rent premiums earned by these disparate groups rules out any special rent-shifting role for unions, and seems to support alternative models of rent-sharing.

The dispersion in wages within the airline sector has also risen after deregulation. Individual microdata from the 1980 and 1990 Census suggest that the increases in earnings inequality for most occupation groups were comparable to or slightly larger than the increases experienced in other sectors of the economy over the 1980s. Union contract data for three main occupation groups (pilots, flight attendants, mechanics) show a noticeable rise in inter-firm wage inequality, especially for pilots. The magnitude of the wage differentials across firms has closed somewhat since the mid-1980s, but remains high: up to 40 percent for pilots, and 10-30 percent for flight attendants.

Despite the passage of nearly two decades since the lifting of airline regulation, the full impact of deregulation is still unclear. Many of the surviving incumbent airline firms are in a relatively precarious financial condition, and their employees continue to face demands for wage cuts. It may take another 20 years to reach a complete assessment of the labor market effects of deregulation. 


\section{References}

Air Transport Association of America. Air Transport (various years). Washington DC: ATA.

American Airlines. Annual Report (various years). Dallas: American Airlines.

Bailey, Elizabeth, David Graham and Daniel Kaplan. Deregulating the Airlines. Cambridge, MA: MIT Press, 1985.

Blau, Francine and Lawrence Kahn. "The Gender Eamings Gap: Some International Differences". In Richard Freeman and Lawrence Katz, editors, Differences and Changes in Wage Structures. Chicago: University of Chicago Press, 1995.

Brown, Anthony E. The Politics of Airline Regulation. Knoxville: University of Tennessee Press, 1987.

Capelli, Peter. "Competitive Pressures and Labor Relations in the Airline Industry". Industrial Relations 24 (Fall 1985): 316-338.

Bargaining in American Industry. Lexington MA: Lexington Books, 1987.

Deregulation". Monthly Labor Review 108 (June 1985): 37-39.

Card, David. "The Impact of Deregulation on the Employment and Wages of Airline Mechanics". Industrial and Labor Relations Review 39 (July 1986): 527-538.

. "Deregulation and Labor Earnings in the Airline Industry." Princeton University Industrial Relations Section Working Paper No. 247, January 1989.

and Thomas Lemieux. "Wage Dispersion, Returns to Skill, and Black-White Wage Differentials". Joumal of Econometrics 74 (1996) forthcoming.

Caves, Richard. Air Transport and Its Regulators. Cambridge MA: Harvard University Press, 1962.

Caves, Douglas, Laurits Christensen, Michael Tretheway and Robert Windle. "An Assessment of the Efficiency Effects of U.S. Airline Deregulation via an International Comparison". In Elizabeth Bailey, editor: Public Regulation: New Perspectives on Institutions and Policies. Cambridge MA: MIT Press, 1987. 
Cremieux, Pierre-Yves. "Why Strike Insurance is Unilateral: Evidence from the Airline Industry's Mutual Aid Pact". Unpublished Manuscript, University of Quebec at Montreal Department of Economics, 1995.

Attendants and Mechanics, $1959-1992$ " Industal and (January 1996):223-242.

Delta Airlines. Annual Report (various years). Atlanta: Delta Airlines.

Devany, Arthur. "The Effect of Price and Entry Regulation on Airline Output Capacity and Efficiency". Bell Joumal of Economics 6 (Spring 1975): 327-345.

Douglas, George and James Miller. "Quality Competition, Industry Equilibrium, and Efficiency in the Price Constrained Airline Market". American Economic Review 64 (September 1974): 657-669.

Eads, George. Competition in the Domestic Trunk Airline Industry: Too Much or Too Littlen. In Almarin Phillips, editor: Promoting Competition in Regulated Industries. Washington DC: The Brookings Institution, 1975.

Farber, Henry S. "The Changing Face of Job Loss in the United States, 1981-1993". Princeton University Industrial Relations Section Working Paper No. 360, March 1996.

Graham, David R. and Daniel P. Kaplan. Competition and the Airlines: An Evaluation of Deregulation. Washington DC: Civil Aeronautics Board, 1982.

Helwege, Jean. "Sectoral Shifts and Interindustry Wage Differentials". Journal of Labor Economics 10 (January 1992): 55-84.

Hendricks, Wallace. "The Effect of Regulation on Collective Bargaining in Electric Utilities". Bell Journal of Economics 6 (Autumn 1975): 451-465. 1977): 483-496. Bargaining in Airlines". Industrial and Labor Relations Review 34 (October 1980): 6781.

Hirsch, Barry. "Trucking Regulation, Unionization, and Labor Earnings: 1973-85". Journal of Human Resources 23 (Spring 1988): 296-319. 
and David A. Macpherson. "Labor Eamings, Rents, and Competition in the Airline Industry, 1973-1993." Unpublished Manuscript, Florida State University Department of Economics, 1994a.

and Union Membership and Earnings Data Book 1994: Compilations from the Current Population Survey. Washington DC: BNA, $1994 \mathrm{~b}$.

International Air Transport Association. World Air Transport Statistics (various issues). Montreal, Canada: IATA.

Kahn, Mark. "Airlines". In Gerald Somers, editor: Collective Bargaining: Contemporary American Experience. Madison WI: Industrial Relations Research Association, 1980.

Keeler, Theodore E. "The Revolution in Airline Regulation." In Leonard Weiss and Michael Klass, editors, Case Studies in Regulation: Revolution and Reform. Boston: Little, Brown, 1981.

Kennet, D. Mark. "Airline Deregulation and Aircraft Engine Maintenance: Reduced Form and Structural Estimation". Unpublished Manuscript, University of California Santa Cruz Department of Economics, 1988.

Lewis, H. Gregg. Unionism and Relative Wages in the United States. Chicago: University of Chicago Press, 1963.

Levy, Frank and Richard Murnane. "U.S. Earnings Levels and Earnings Inequality: A review of Recent Trends and Proposed Explanations". Joumal of Economic Literature 30 (September 1992): 1333-1381.

Moore, Thomas Gale. "The Beneficiaries of Trucking Regulation". Joumal of Law and Economics 21 (October 1978): 327-344.

Joumal of Law and Economics 24 (April 1986): 1-28.

Morrison, Steven and Clifford Winston. The Economic Effects of Airline Deregulation. Washington DC: The Brookings Institution, 1986.

Neal, Derek. "Industry-Specific Human Capital: Evidence from Displaced Workers". Journal of Labor Economics 13 (October 1995): 653-677.

Parent, Daniel. "Industry-Specific Human Capital and the Wage Profile: Evidence from the NLSY and the PSID ${ }^{n}$. Princeton University Industrial Relations Section Working Paper No. 350, November 1995. 
Rose, Nancy. "The Incidence of Regulatory Rents in the Motor Carrier Industry". Rand Joumal of Economics 16 (Autumn 1985): 299-318.

Rose, Nancy. "Labor Rent Sharing and Regulation: Evidence from the Trucking Industry". Journal of Political Economy 95 (December 1987): 1146-1178.

Unterberger, S. Herbert and Edward Koziara. "Airline Strike Insurance: A Study in Escalation". Industrial and Labor Relations Review 30 (April 1977): 364-379.

United States Department of Labor Bureau of Labor Statistics. Report on the American Workforce. Washington DC: USGPO, 1994.

United States Department of Transport. "Airport Activity Statistics of Certified Route Carriers". Washington DC: USGPO, 1994.

Walsh, David. "Accounting for the Proliferation of Two-Tier Wage Settlements in the U.S. Airline Industry, 1983-86". Industrial and Labor Relations Review 42 (October 1988): 50-62.

Williams, George. The Airline Industry and the Impact of Deregulation. Brookfield Vt: Ashgate Publishing, 1994. 


\section{Data Appendix}

\section{Census and CPS Microdata}

The samples used in Tables 3-6 are based on extracts from the 1980 and 1990 5-percent Census public use micro sample files, and the March 1994 and March 1995 Current Population Surveys. The census files include individuals age 16 and older with positive non-allocated earnings, positive weeks of work and positive hours per week in the previous year, who report a valid nonallocated 3-digit industry for their main job in the last year. The final census extracts include all individuals who worked in the airline industry (Census industry code 421) and a 5 percent random sample of all other workers. The CPS extracts include all individuals age 16 and older with positive non-allocated earnings, positive weeks of work and positive hours per week in the previous year. For the earnings models I further limit the 1980 sample to individuals with average hourly earnings between $\$ 2$ and $\$ 84$ per hour and average weekly earnings under $\$ 3360$; the 1990 sample to individuals with average hourly earnings between $\$ 3.17$ and $\$ 132$ per hour and average weekly earnings under $\$ 5280$; and the $1994-95$ sample to individuals with average hourly earnings between $\$ 3.50$ and $\$ 150$ per hour and average weekly earnings under $\$ 6000$.

\section{Displaced Worker Surveys}

The samples used in Tables 8-10 include all individuals in the 1984, 1986, 1988, 1990, 1992, and 1994 displaced worker supplements who reported losing a job in the previous 5 years (previous 3 years in 1994). Individuals who report a weekly wage of less than $\$ 10$ per week are excluded from the earnings analysis. The models reported in Tables 9 and 10 are fit to a subsample of observations with non-missing data on age, year of displacement, tenure on the 
previous job, education, and weekly earnings on the pre-displacement and post-displacement job (in column 7 of Table 9 the sample is expanded to include non-workers at the time of the survey). 
Figure 1

Market Shares of Airline Firms

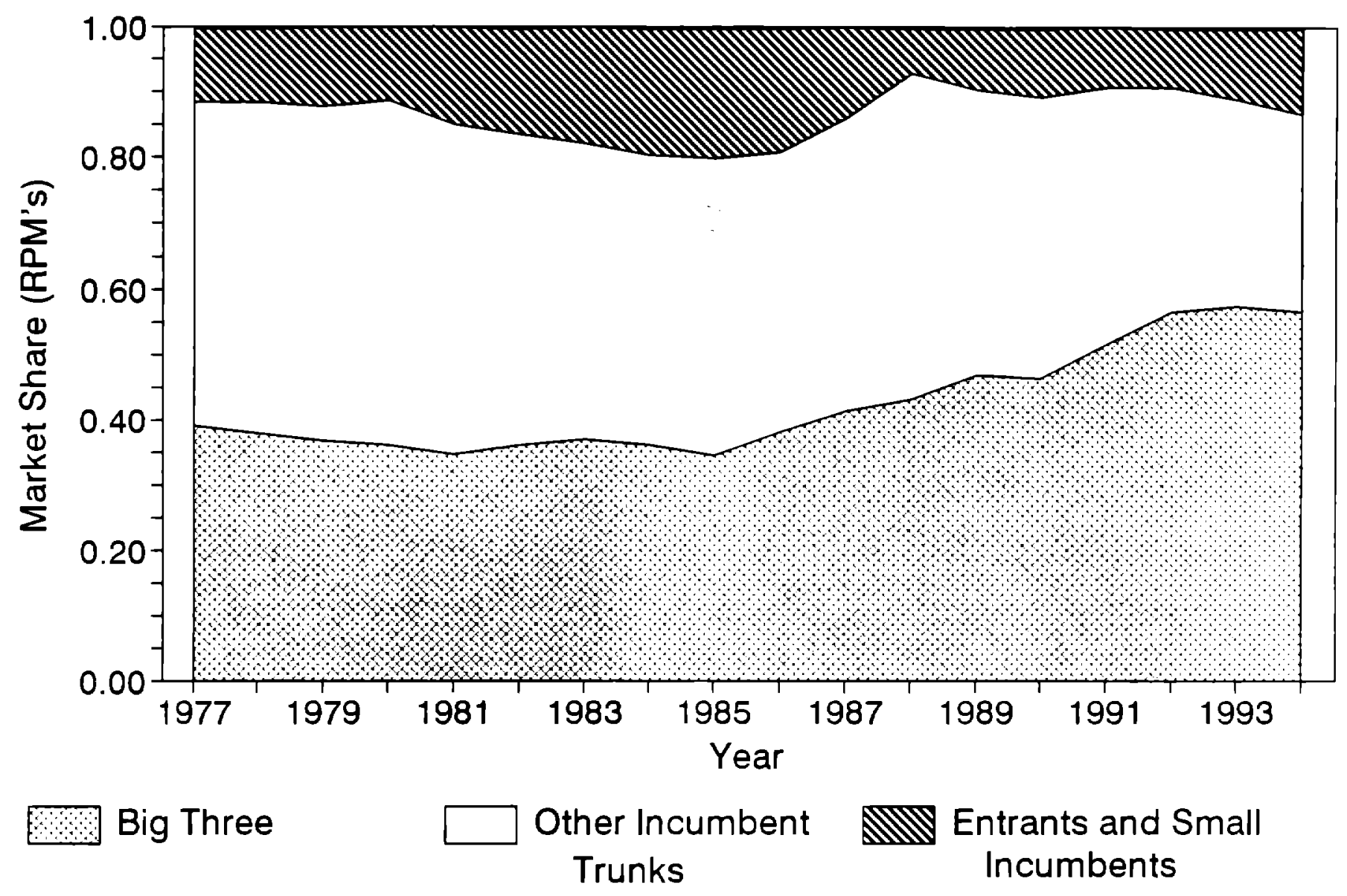


Figure 2: Hourly Wage Distributions of Airline and Non-airline Workers in 1979 (top) and 1989 (bottom)
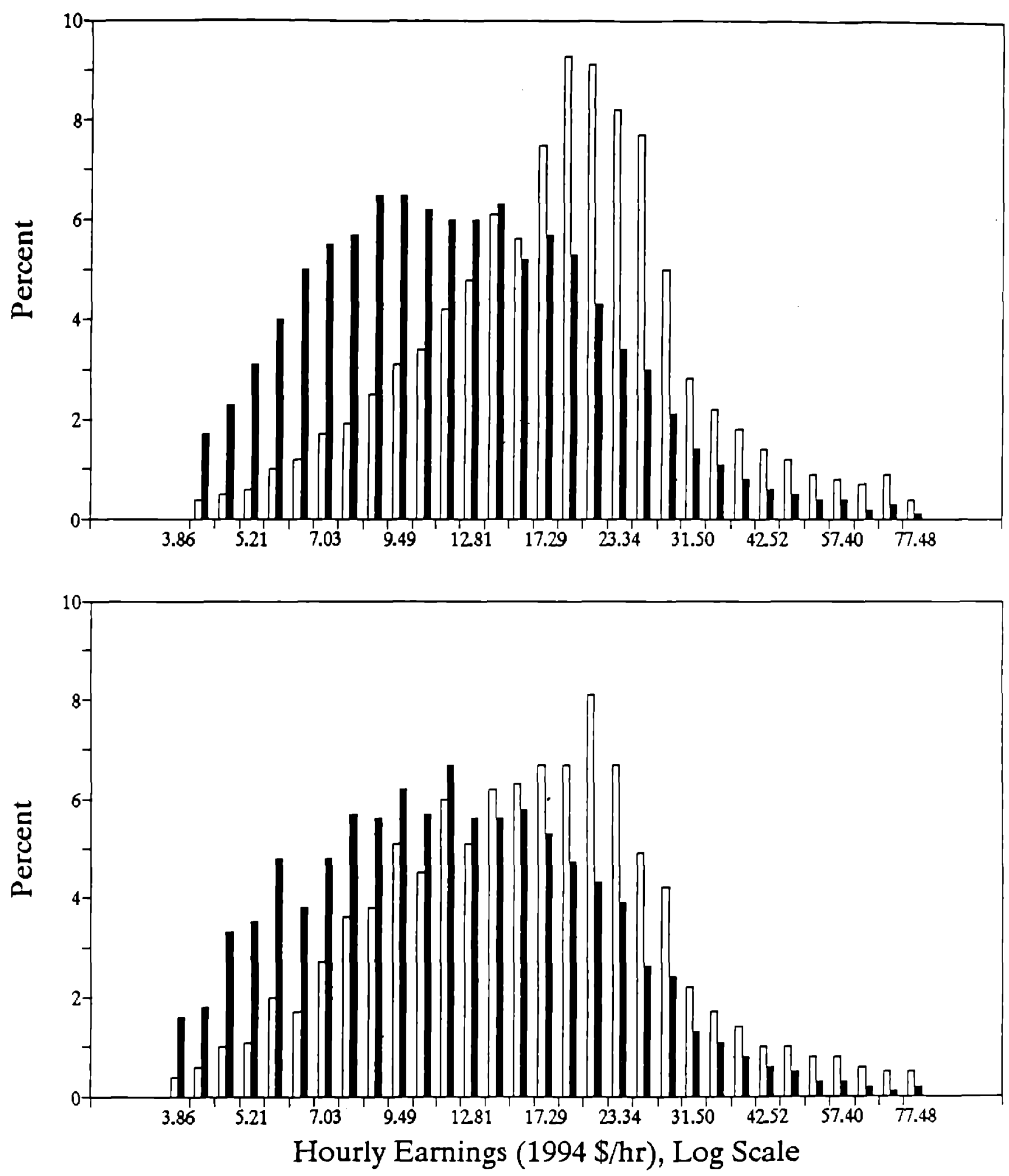

$\square$ Airline $\square$ Non-airline

Note: each horizontal axis tick represents $10 \mathrm{log}$ points 
Table 1: Overall Industry Statistics for the Scheduled Airline Industry, 1968-94

\begin{tabular}{|c|c|c|c|c|c|c|c|c|c|}
\hline & \multicolumn{3}{|c|}{ Passenger Output } & \multirow{2}{*}{$\begin{array}{l}\text { I1 Firm } \\
\text { Share of } \\
\text { Total RPM } \\
(4)\end{array}$} & \multirow{2}{*}{$\begin{array}{l}\text { Domestic } \\
\text { Price (1967 } \\
\text { cents/mile) } \\
\text { (5) }\end{array}$} & \multirow{2}{*}{$\begin{array}{l}\text { Freight } \\
\text { Ton-miles } \\
(6)\end{array}$} & \multirow{2}{*}{$\begin{array}{l}\text { Return on } \\
\text { Investment } \\
\text { (7) }\end{array}$} & \multirow{2}{*}{$\begin{array}{l}\text { Total } \\
\text { Employment } \\
\text { (8) }\end{array}$} & \multirow[b]{2}{*}{$\begin{array}{c}\text { RPH's per } \\
\text { Employee } \\
(9)\end{array}$} \\
\hline & $\begin{array}{l}\text { RPM } \\
\text { (1) }\end{array}$ & $\begin{array}{l}\text { ASM } \\
(2)\end{array}$ & $\begin{array}{l}\text { Loed } \\
\text { (3) }\end{array}$ & & & & & & \\
\hline 1968 & 114.0 & 216.4 & 52.7 & 0.92 & 5.4 & 3.4 & 4.0 & 311.922 & 365 \\
\hline 1978 & 226.8 & 368.8 & 61.5 & 0.91 & 4.3 & 5.8 & 13.3 & 329,303 & 689 \\
\hline 1980 & 255.2 & 432.5 & 59.0 & 0.86 & 4.7 & 5.7 & 5.3 & 371,068 & 688 \\
\hline 1982 & 259.6 & 440.1 & 59.0 & 0.80 & 4.2 & 5.5 & 2.1 & 330,795 & 785 \\
\hline 1984 & 305.1 & 515.3 & 59.2 & 0.77 & 4.1 & 6.6 & 9.9 & 345,079 & 884 \\
\hline 1986 & 366.5 & 607.4 & 60.3 & 0.81 & 3.4 & 7.3 & 4.9 & 421,686 & $966^{*}$ \\
\hline 1988 & 423.3 & 676.8 & 62.5 & 0.91 & 3.5 & 9.6 & 10.8 & 480,553 & $1,004^{\circ}$ \\
\hline 1990 & 457.9 & 733.4 & 62.4 & 0.91 & 3.4 & 10.5 & -6.0 & 545,809 & $983^{*}$ \\
\hline 1992 & 478.6 & 752.8 & 63.6 & 0.91 & 3.1 & 11.1 & -9.3 & 540,413 & $1,049^{\star}$ \\
\hline 1994 & 519.2 & 783.8 & 66.2 & 0.87 & 2.9 & 13.7 & 5.3 & 543,325 & $1,152^{\star}$ \\
\hline \multicolumn{4}{|c|}{ Growth Rate (percent per year) } & & . & & & & \\
\hline $1968 \cdot 78$ & 7.1 & 5.5 & - & - & -2.3 & 5.7 & $\cdots$ & 0.5 & 6.5 \\
\hline $1978-94$ & 5.3 & 4.8 & - & -. & -2.4 & 5.5 & -. & $3.2 / 2.0^{\circ}$ & $3.3^{\star}$ \\
\hline
\end{tabular}

Notes: Data are taken from ATA Air Transport, various issues.

- Denotes that Federal Express employment is excluded from this calcuation.

Colum 1: billions of revenue passenger miles (RPM) flown in scheduled airline industy.

Colum 2: billions of available seat-miles flown in scheduled airline industy

Colum 3: ratio of revenue pessenger miles to available seat miles ("load factor").

Colum 4: fraction of industry RPM's accounted for by 11 major pre-deregulation firms.

Colum 5: passenger reverues per mile, in 1967 cents per mile.

Colum 6: billions of freight and express ton-miles shipped by scheduled carriers.

Colum 7: accounting measure of race of return on investment (for industry as a whole).

Colum 8: totsl employment in scheduled airline industry. Addition of Federal Express to industry in 1986 adds 42,452 employees $(92,511$ in 1994). Second entry in botton row is calculated excluding federal Express employment.

Colum 9: thousands of revenue passenger miles per employee. Federal Express employment is excluded from industry employment total after 1986 in calculating this ratio. 
Table 2: Real Average Weekly Earnings: Airline Workers and All Workers

\begin{tabular}{|c|c|c|c|c|}
\hline & \multicolumn{3}{|c|}{ Airline Workers } & \multirow{2}{*}{$\begin{array}{c}\text { All Private } \\
\text { Non-Supervisory } \\
\text { Employees } \\
\text { (4) }\end{array}$} \\
\hline & $\begin{array}{l}\text { FAA/ATA } \\
\text { Handbook } \\
\text { (1) }\end{array}$ & $\begin{array}{l}\text { IWS } \\
\text { (2) }\end{array}$ & $\begin{array}{l}\text { May/OGR } \\
\text { CPS } \\
\text { (3) }\end{array}$ & \\
\hline 1975 & 981 & 967 & 809 & 463 \\
\hline 1979 & $\cdots$ & -- & 800 & 461 \\
\hline 1980 & $\cdots$ & 990 & 781 & 434 \\
\hline 1981 & - & -- & 793 & 427 \\
\hline 1982 & 959 & - & 809 & 422 \\
\hline 1983 & 993 & -- & 838 & 430 \\
\hline 1984 & 956 & 963 & 786 & 434 \\
\hline 1985 & $\ldots$ & $\cdots$ & 784 & 428 \\
\hline 1986 & $\cdots$ & - & 805 & 429 \\
\hline 1987 & $-\cdot$ & - & 764 & 425 \\
\hline 1988 & -- & $\cdots$ & 778 & 421 \\
\hline 1989 & $\cdots$ & -- & 754 & 417 \\
\hline 1990 & - & - & 757 & 410 \\
\hline 1991 & 848 & -- & 729 & 403 \\
\hline 1992 & 847 & - & 723 & 403 \\
\hline 1993 & 843 & -- & 720 & 403 \\
\hline 1994 & 855 & $\cdots$ & -- & 406 \\
\hline
\end{tabular}

Note: All entries represent weekly earnings in 1995 dollars, deflated by CPI-U.

Colum 1: 1975 entry is from FAA Statistical Handbook of Aviation, 1976. 1982-94 entries are from ATA Air Transport, and represent annual wages (excluding fringes) divided by 52 .

Column 2: From BLS Industry Wage Surveys, Bulletins 1951, 2129, and 2241 .

Column 3: From Hirsch and Macpherson (1994), Table 2. Based on average weekly earnings of full-time private sector workers in the May 1975 and 1976 CPS surveys (1975 entry) and in the merged outgoing rotation group files of the CPS for 1979-93.

Column 4: From 1996 Economic Report of the President Table B-43. 
Table 3: Mean Characteristics of Airline and Non-Airline Workers, 1980 Census, 1990 Census, and 1994/95 CPS Samples

\begin{tabular}{|c|c|c|c|c|c|c|}
\hline \multirow[b]{2}{*}{. } & \multicolumn{2}{|c|}{1980 Census } & \multicolumn{2}{|c|}{1990 Census } & \multicolumn{2}{|c|}{$1994 / 95$ CPS } \\
\hline & Alrline & Other & Airline & Other & Airline & Other \\
\hline 1. Sample Size & 22,744 & 205,742 & 30,705 & 236,527 & 789 & 116,887 \\
\hline 2. Mean Education & 13.3 & 12.6 & 13.7 & 13.2 & 13.9 & 13.3 \\
\hline 3. Percent Female & 32.4 & 43.7 & 35.1 & 46.4 & 37.9 & 47.1 \\
\hline 4. Percent Nonwhite & 12.2 & 12.6 & 14.5 & 14.2 & 17.9 & 14.6 \\
\hline 5. Percent Veterans & 37.0 & 22.5 & 28.5 & 16.5 & - & - \\
\hline \multicolumn{7}{|c|}{ Earnings Data (1995 Dollars): } \\
\hline 6. Mean Weekly Wage & 871.4 & 573.1 & 811.5 & 602.0 & 719.7 & 541.7 \\
\hline 7. Mean Hourly Wage & 24.54 & 15.24 & 20.88 & 15.08 & 19.66 & 13.55 \\
\hline $\begin{array}{l}\text { 8. Mean Log Hourly } \\
\text { Wage }\end{array}$ & 2.988 & 2.530 & 2.819 & 2.505 & 2.758 & 2.423 \\
\hline $\begin{array}{l}\text { 9. Std. Dev. of Log } \\
\text { Hourly Wage }\end{array}$ & 0.608 & 0.586 & 0.626 & 0.611 & 0.622 & 0.589 \\
\hline $\begin{array}{l}\text { 10. Interquartile Range } \\
\text { of Log Hourly Wage }\end{array}$ & 0.650 & 0.823 & 0.771 & 0.873 & 0.674 & 0.870 \\
\hline $\begin{array}{l}\text { 11. } 90-10 \text { Percentile } \\
\text { Range of Log Hourly } \\
\text { Wage }\end{array}$ & 1.458 & 1.466 & 1.504 & 1.553 & 1.523 & 1.556 \\
\hline
\end{tabular}

Notes: Samples are described in Data Appendix. Samples include individuals who worked in the previous year and reported positive (non-allocated) earnings. 1980 and 1990 Census samples exclude Individuals with allocated industry. Earnings data pertain to previous year: 1979, 1989, or an average of 1993 and 1994, and are inflated to 1995 levels using the CPI. 
Table 4: Estimated Hourly Wage Premiums for Airline Industry

\begin{tabular}{|c|c|c|c|c|c|c|}
\hline & \multicolumn{2}{|c|}{1979} & \multicolumn{2}{|c|}{1989} & \multicolumn{2}{|c|}{$1993 / 4$} \\
\hline & (1) & (2) & (3) & (4) & (5) & (6) \\
\hline Models with Single & Airline Indu & try Dummy & & & & \\
\hline $\begin{array}{l}\text { Airline Wage } \\
\text { Differential }\end{array}$ & $\begin{array}{c}0.458 \\
(0.004)\end{array}$ & $\begin{array}{c}0.314 \\
(0.003)\end{array}$ & $\begin{array}{c}0.314 \\
(0.004)\end{array}$ & $\begin{array}{c}0.227 \\
(0.003)\end{array}$ & $\begin{array}{c}0.335 \\
(0.021)\end{array}$ & $\begin{array}{c}0.225 \\
(0.017)\end{array}$ \\
\hline Added Covariates: & No & Yes & No & Yes & No & Yes \\
\hline
\end{tabular}

Models with Interaction Effects for Specialized Occupations:

\begin{tabular}{lcccccc} 
Airline Wage & 0.324 & 0.203 & 0.170 & 0.119 & 0.198 & 0.130 \\
$\begin{array}{l}\text { Differential for } \\
\text { Non-specialized } \\
\text { Occupations }\end{array}$ & $(0.005)$ & $(0.004)$ & $(0.004)$ & $(0.004)$ & $(0.025)$ & $(0.021)$ \\
& & & & & & \\
$\begin{array}{l}\text { Differential for } \\
\text { Pilots }\end{array}$ & 1.148 & 0.754 & 0.977 & 0.609 & 0.992 & 0.605 \\
& $(0.012)$ & $(0.010)$ & $(0.010)$ & $(0.009)$ & $(0.058)$ & $(0.047)$ \\
Differential for & 0.583 & 0.657 & 0.444 & 0.481 & 0.436 & 0.416 \\
Flight Attendents & $(0.012)$ & $(0.010)$ & $(0.010)$ & $(0.009)$ & $(0.064)$ & $(0.052)$ \\
$\begin{array}{l}\text { Differential for } \\
\text { Mechanics }\end{array}$ & 0.473 & 0.216 & 0.347 & 0.224 & 0.314 & 0.174 \\
Added Covariates: & $(0.012)$ & $(0.010)$ & $(0.010)$ & $(0.008)$ & $(0.064)$ & $(0.052)$ \\
& No & Yes & No & Yes & No & Yes \\
\hline
\end{tabular}

Notes: Standard errors in parentheses. Covariates included in columns 2, 4, 6 are: education, cubic in experience, dummies for female, nonwhite, hispanic, married, veteran status, residence outside a metropolitan area, residence in 8 census divisions, and interactions of experience terms and married dumny with female dummy. 
Table 5: Estimated Wage Differentials for Specific Employee Groups in the Atrline Industry

\begin{tabular}{llcl}
\hline Employee Group & $\begin{array}{c}\text { Group-specific } \\
\text { Airline Wage } \\
\text { Differential } \\
\text { in } 1979\end{array}$ & $\begin{array}{c}\text { Change in } \\
\text { Airline Wage } \\
\text { Differential } \\
1979 \text { to } 1989\end{array}$ \\
\hline 1. Al1 - Hourly Wage & 0.314 & -0.087 \\
& - Weekly Wage & 0.295 & $(0.004)$ \\
& & $(0.004)$ & -0.063 \\
& & $(0.006)$
\end{tabular}

By Occupation (Pooled Model):
2. Pilots - Hourly Wage

$\begin{array}{ll}0.754 & -0.145 \\ (0.010) & (0.013) \\ 0.546 & -0.027 \\ (0.010) & (0.015)\end{array}$
3. F1. Att. - Hourly Wage
0.657
$(0.010)$
$-0.176$
- Weekly Wage
(0.013)
- Weekly Wage
0.519
$(0.010)$
$-0.113$
$(0.015)$
4. Mechanics (Hourly)
0.216
0.008
$(0.010)$
$(0.013)$
5. All Non-specialized
0.203
$-0.084$ Occcupations (Hourly)
$(0.004)$
$(0.006)$

By Education (Pooled Model):
6. 12 or Fewer Years of Education (Hourly)
0.309
(0.005)
$-0.062$
$(0.007)$
7. 13 or More Years of
Education (Hourly)
0.332
$-0.102$
$(0.005)$
(0.006)

For Narrow Occupation Groups (Occupation-specific Models):
8. Managers (Hourly)
0.139
$(0.011)$
$-0.110$
$(0.019)$
9. Secretaries (Hourly)
0.175
$(0.017)$
$-0.084$
$(0.026)$
Notes: Standard errors in parentheses. All differentials are obtained from regression models that include the covariates listed in the note to Table 4. Differentials are for log hourly wage or $\log$ weekly wage, as noted. Models in rows $1-7$ are estimated using a pooled sample of all airline and non-airline workers. Models in rows 8 and 9 are estimated on occupation-specific samples.


Table 6: Changes in the Dispersion of Hourly and Weekly Wages, 1979 to 1989

\begin{tabular}{|c|c|c|c|}
\hline & 1979 & 1989 & Change \\
\hline \multicolumn{4}{|l|}{ Non-AIrline Workers: } \\
\hline 1. Std. Dev. Log Hourly Wage & $\begin{array}{c}0.586 \\
(0.001)\end{array}$ & $\begin{array}{c}0.611 \\
(0.001)\end{array}$ & $\begin{array}{l}0.025 \\
(0.001)\end{array}$ \\
\hline 2. Std. Dev. Log Weekly Wage & $\begin{array}{c}0.719 \\
(0.001)\end{array}$ & $\begin{array}{c}0.772 \\
(0.001)\end{array}$ & $\begin{array}{c}0.052 \\
(0.002)\end{array}$ \\
\hline \multicolumn{4}{|l|}{ All Airline Workers: } \\
\hline 3. Std. Dev. Log Hourly Wage & $\begin{array}{c}0.608 \\
(0.004)\end{array}$ & $\begin{array}{l}0.626 \\
(0.003)\end{array}$ & $\begin{array}{l}0.018 \\
(0.005)\end{array}$ \\
\hline 4. Std. Dev. Log Weekly Wage & $\begin{array}{l}0.580 \\
(0.004)\end{array}$ & $\begin{array}{l}0.654 \\
(0.003)\end{array}$ & $\begin{array}{c}0.073 \\
(0.005)\end{array}$ \\
\hline Pilots: & 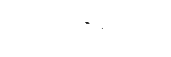 & & \\
\hline 5. Std. Dev. Log Hourly Wage & $\begin{array}{c}0.848 \\
(0.009)\end{array}$ & $\begin{array}{c}0.793 \\
(0.008)\end{array}$ & $\begin{array}{l}-0.055 \\
(0.012)\end{array}$ \\
\hline 6. Std. Dev. Log Weekly Wage & $\begin{array}{c}0.706 \\
(0.010)\end{array}$ & $\begin{array}{c}0.733 \\
(0.008)\end{array}$ & $\begin{array}{l}0.027 \\
(0.013)\end{array}$ \\
\hline \multicolumn{4}{|l|}{ Flight Attendents: } \\
\hline 7. Std. Dev, Log Hourly Wage & $\begin{array}{l}0.585 \\
(0.008)\end{array}$ & $\begin{array}{c}0.608 \\
(0.007)\end{array}$ & $\begin{array}{c}0.023 \\
(0.011)\end{array}$ \\
\hline 8. Std. Dev. Log Weekly Wage & $\begin{array}{c}0.407 \\
(0.010)\end{array}$ & $\begin{array}{c}0.491 \\
(0.008)\end{array}$ & $\begin{array}{c}0.084 \\
(0.013)\end{array}$ \\
\hline \multicolumn{4}{|l|}{ Mechanics: } \\
\hline 9. Std. Dev. Log Hourly Wage & $\begin{array}{c}0.446 \\
(0.009)\end{array}$ & $\begin{array}{c}0.482 \\
(0.006)\end{array}$ & $\begin{array}{c}0.036 \\
(0.011)\end{array}$ \\
\hline 10. Std. Dev. Log Weekly Wage & $\begin{array}{c}0.454 \\
(0.010)\end{array}$ & $\begin{array}{l}0.502 \\
(0.008)\end{array}$ & $\begin{array}{c}0.048 \\
(0.013)\end{array}$ \\
\hline \multicolumn{4}{|l|}{ Non-specialized Occupations: } \\
\hline 11. Std. Dev. Log Hourly Wage & $\begin{array}{l}0.499 \\
(0.004)\end{array}$ & $\begin{array}{l}0.533 \\
(0.003)\end{array}$ & $\begin{array}{l}0.034 \\
(0.005)\end{array}$ \\
\hline 12. Std. Dev. Log Weekly Wage & $\begin{array}{l}0.537 \\
(0.004)\end{array}$ & $\begin{array}{c}0.611 \\
(0.004)\end{array}$ & $\begin{array}{c}0.075 \\
(0.006)\end{array}$ \\
\hline
\end{tabular}

Notes: Standard errors in parentheses. 
Table 7a: Hourly Wage Rates for 727 Captains at Incumbent Firms

\begin{tabular}{|c|c|c|c|c|c|c|}
\hline & \multicolumn{2}{|c|}{ December 1980} & \multicolumn{2}{|c|}{ December 1987} & \multicolumn{2}{|c|}{ January 1995} \\
\hline & $\begin{array}{l}\text { Wage } \\
(\$ / \mathrm{hr} r)\end{array}$ & Number & $\begin{array}{l}\text { Wage } \\
(\$ / \mathrm{hr})\end{array}$ & Number & $\begin{array}{l}\text { Wage } \\
(\$ / h r)\end{array}$ & Number \\
\hline American & 96 & 4,502 & 125 & 6,344 & 165 & 9,349 \\
\hline Braniff & $99^{*}$ & 1,439 & 57 & 1,006 & - & 0 \\
\hline Continental & 92 & 1,555 & 53 & 3,946 & 90 & 4,205 \\
\hline Delta & $100^{*}$ & 3,658 & 140 & 5,264 & 166 & 8,333 \\
\hline Eastern & 90 & 4,116 & 93 & 4,985 & - & 0 \\
\hline Northwest & 90 & 1,517 & 136 & 4,557 & 158 & 4,965 \\
\hline Pan Am & 95 & 2,932 & 113 & 2,159 & - & 0 \\
\hline Transworld & 88 & 3,344 & 88 & 2,969 & $\mathrm{n} / \mathrm{a}$ & 2,347 \\
\hline USAir & 100 & 1,062 & 141 & 1,794 & 158 & 4,993 \\
\hline United & 92 & 5,669 & 128 & 6,268 & 137 & 7,889 \\
\hline Western & 89 & 1,560 & $\cdots$ & 0 & -- & 0 \\
\hline $\begin{array}{l}\text { Average or Total } \\
\text { for } 11 \text { Firms }\end{array}$ & 93 & 31,354 & 113 & 39,292 & 150 & 42,081 \\
\hline $\begin{array}{l}\text { Average Wage in } \\
1995 \$\end{array}$ & 173 & & 152 & & 150 & \\
\hline $\begin{array}{l}\text { Coefficient of } \\
\text { Variation }(z)\end{array}$ & 4.3 & & 24.9 & & 15.5 & \\
\hline
\end{tabular}

Notes: Employment counts include captains, first and second officers, and flight engineers. Wage rates are calculated for a captain of a Boeing 727 aircraft, flying 50 percent night hours, with 10 years of seniority. Wages are obtained from union contracts on file with National Mediation Board or other sources. Employment counts are from Form 41 reports (1980 and 1987) or IATA World Air Transport Statistics (1995). Average wages in 1995 do not include Transworld.

"Estimate. 
Table 7b: Monthly Wage Rates for Flight Attendents at Incumbent Firms

\begin{tabular}{|c|c|c|c|c|c|c|}
\hline & \multicolumn{2}{|c|}{ December 1980} & \multicolumn{2}{|c|}{ December 1987} & \multicolumn{2}{|c|}{ January 1995} \\
\hline & $\begin{array}{l}\text { Wage } \\
(\$ / \text { mo })\end{array}$ & Number & $\begin{array}{l}\text { Wage } \\
(\$ / \mathrm{mo})\end{array}$ & Number & $\begin{array}{l}\text { Wage } \\
(\$ / \text { mo })\end{array}$ & Number \\
\hline American & 1,470 & 6,263 & $1,910 / 1,369$ & 10,292 & $1,853 / 1328$ & 18,008 \\
\hline Braniff & 1,136 & 2,330 & $1,300^{\star}$ & 411 & - - & 0 \\
\hline Continental & 1,347 & 2,175 & $1,374^{*}$ & 6,068 & 1,300 & 5,698 \\
\hline Eastern & 1,402 & 5,893 & 1,579 & 8,112 & - & 0 \\
\hline Northwest & 1,208 & 2,481 & $1,840 / 1248$ & 6,347 & 1,311 & 8,603 \\
\hline Pan Am & 1,415 & 6,078 & $1,922 / 1281$ & 3,838 & 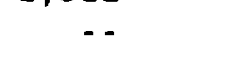 & 0 \\
\hline Transworld & 1,327 & 5,534 & $1,704 / 1333$ & 4,517 & 1,275 & 4,446 \\
\hline USAir & 1,347 & 1,370 & $1,897 / 1340$ & 2,486 & 1,483 & 8,128 \\
\hline United & 1,298 & 8,829 & $1,732 / 1361$ & 11,755 & 1,623 & 18,243 \\
\hline Western & 1,349 & 2,083 & $\cdots$ & 0 & -- & 0 \\
\hline $\begin{array}{l}\text { Average or } \\
\text { Total for } \\
10 \text { Firms }\end{array}$ & 1,350 & 43,036 & 1,552 & 53,826 & 1,500 & 63,126 \\
\hline $\begin{array}{l}\text { Average Wage } \\
\text { in } 1995 \$\end{array}$ & 2,497 & & 2,082 & & 1,500 & \\
\hline $\begin{array}{l}\text { Coefficient of } \\
\text { Variation ( } 8)\end{array}$ & 6.3 & & 5.0 & & 9.1 & \\
\hline
\end{tabular}

Notes: Wage rates are calculated for a flight attendent with 5 years of seniority flying 65 hours per month. In cases where two rates are reported, the second pertains to the wage for employees on the lower scale of a two-tier pay system. Weighted average wages in bottom two rows assume one half of of employees work at the lower-tier wage. See Table $7 a$ for sources.

"Estimate. 
Table 7c: Hourly Wage Rates for Mechanics at Incumbent Firms

\begin{tabular}{|c|c|c|c|c|c|c|}
\hline & \multicolumn{2}{|c|}{ Deceuber 1980} & \multicolumn{2}{|c|}{ December 1987} & \multicolumn{2}{|c|}{ January 1995} \\
\hline & $\begin{array}{l}\text { Wage } \\
(\$ / \mathrm{hr})\end{array}$ & Number & $\begin{array}{l}\text { Wage } \\
(\$ / h r)\end{array}$ & Number & $\begin{array}{l}\text { Wage } \\
(\$ / \mathrm{hr})\end{array}$ & Number \\
\hline American & 12.66 & 6,001 & 17.89 & 7,064 & 22.25 & 11,232 \\
\hline Braniff & 12.40 & 1,355 & -. & 0 & - - & 0 \\
\hline Continental & 12.22 & 1,151 & 15.00 & 3,617 & $n / a$ & 4,472 \\
\hline Eastern & 12.99 & 7,207 & 18.00 & 6,518 & $\therefore$ & 0 \\
\hline Northwest & 12.42 & 1,407 & 18.50 & 3,904 & 21.00 & 8,727 \\
\hline Pan Am & 12.50 & 4,250 & 16.40 & 2,976 & - & 0 \\
\hline Transworld & 12.07 & 5,168 & 15.25 & 5,010 & 21.00 & 4,209 \\
\hline USAir & 12.21 & 1,335 & 18.30 & 1,727 & 20.00 & 9,424 \\
\hline United & 12.35 & 5,793 & 18.54 & 7,844 & 19.77 & 14,801 \\
\hline Western & 12.99 & 1,120 & - & 0 & - & 0 \\
\hline $\begin{array}{l}\text { Average or } \\
\text { Total for } \\
11 \text { Firms }\end{array}$ & 12.53 & 34,787 & 17.39 & 38,660 & 20.72 & 52,865 \\
\hline $\begin{array}{l}\text { Averge Wage } \\
\text { in } 1995 \$\end{array}$ & 23.17 & & 23.33 & & 20.72 & \\
\hline $\begin{array}{l}\text { Coefficient of } \\
\text { Variation ( } 8)\end{array}$ & 2.5 & & 7.6 & & 4.7 & \\
\hline
\end{tabular}

Notes: Wage rates are maximum hourly rates for a fully qualified mechanic excluding line service or licence premiums. See Table 7a for sources. Average wages in 1995 do not include Continental.

Estimate. 
Table 8:

Characteristics of Displaced Horkers From All Industries and Fran the Airline Industry: 1979-1994.

\begin{tabular}{|c|c|c|c|}
\hline & \multirow[b]{2}{*}{ All } & \multicolumn{2}{|c|}{ Displaced From Airl ine Industry: } \\
\hline & & All & Excluding Pilots \\
\hline 1. Sample size & 46,374 & 342 & 300 \\
\hline \multicolumn{4}{|c|}{ 2. Demographic Characteristics: } \\
\hline a. Percent fenole & 39.7 & 33.0 & 37.0 \\
\hline b. Percent Monwhite & 14.5 & 15.7 & 17.3 \\
\hline $\begin{array}{l}\text { c. Percent with Some } \\
\text { College }\end{array}$ & 23.7 & 33.4 & 34.8 \\
\hline $\begin{array}{l}\text { d. Percent with College } \\
\text { Degree }\end{array}$ & 15.8 & 25.7 & 21.9 \\
\hline e. Mean Years of Education & 12.6 & 13.6 & 13.4 \\
\hline $\begin{array}{l}\text { f. Mesn Age at Time of } \\
\text { Job Loss }\end{array}$ & 35.2 & 35.2 & 35.1 \\
\hline \multicolumn{4}{|l|}{ 3. Characteristics of old Job: } \\
\hline $\begin{array}{l}\text { a. Mean Weekly Wage } \\
(1994 \mathrm{~s})\end{array}$ & 457.2 & 589.9 & 553.1 \\
\hline $\begin{array}{l}\text { b. Median Weekly Wage } \\
(1994 \mathrm{~S})\end{array}$ & 382.5 & 556.2 & 512.6 \\
\hline c. Mean Tenure (years) & 4.6 & 5.9 & 6.1 \\
\hline \multicolumn{4}{|c|}{ 4. Post-Displacement Experiences: } \\
\hline $\begin{array}{l}\text { a. Median Ueeks of } \\
\text { Uneripl oyment }\end{array}$ & 9 & 11 & 10 \\
\hline $\begin{array}{l}\text { b. Percent wi th no } \\
\text { Unemployment }\end{array}$ & 13.3 & 13.8 & 14.2 \\
\hline $\begin{array}{l}\text { c. Percent Re-employed } \\
\text { at Survey }\end{array}$ & 65.0 & $乃 .8$ & $\pi .5$ \\
\hline $\begin{array}{l}\text { d. Percent Moved After } \\
\text { Displacement }\end{array}$ & 16.9 & 24.2 & 16.5 \\
\hline \multicolumn{4}{|c|}{ 5. Characteristics of Those with New Job: } \\
\hline $\begin{array}{l}\text { a. Percent in Original } \\
\text { Industry }\end{array}$ & 24.5 & 38.8 & 36.3 \\
\hline $\begin{array}{l}\text { b. Meen Weekly Wege } \\
\text { Old Job (1994 \$) }\end{array}$ & 481.3 & 597.5 & 552.5 \\
\hline $\begin{array}{l}\text { c. Median Neekly Wage } \\
\text { Old Job (1994 S) }\end{array}$ & 405.6 & 556.2 & 512.6 \\
\hline $\begin{array}{l}\text { d. Mean Heek (y Wage } \\
\text { New Job (1994 \$) }\end{array}$ & 462.6 & 571.6 & 523.3 \\
\hline $\begin{array}{l}\text { e. Median Heekly Hage } \\
\text { New Job (1994 S) }\end{array}$ & 391.6 & 512.5 & 469.5 \\
\hline $\begin{array}{l}\text { f. Mean Percentage. } \\
\text { Wage Change }\end{array}$ & -5.0 & -3.6 & -4.8 \\
\hline $\begin{array}{l}\text { g. Percent with > 10x } \\
\text { Hage Gain }\end{array}$ & 39.3 & 39.2 & 39.4 \\
\hline $\begin{array}{l}\text { h. Percent with }>10 x \\
\text { Wage Loss }\end{array}$ & 38.1 & 42.2 & 42.7 \\
\hline
\end{tabular}




\begin{tabular}{|c|c|c|c|c|c|c|c|}
\hline & \multicolumn{3}{|c|}{ als Models: } & \multicolumn{4}{|c|}{ Quantile Regressions: } \\
\hline & \multicolumn{2}{|c|}{$\begin{array}{l}\text { All re-enployed } \\
\text { workers }\end{array}$} & $\begin{array}{l}\text { Exclude } \\
\text { Pilots } \\
\text { (3) }\end{array}$ & \multicolumn{3}{|c|}{$\begin{array}{l}\text { All re-employed workers: } \\
\begin{array}{lll}25 \text { th } & 50 \text { th } & 75 \text { th } \\
\text { (4) } & \text { (5) } & \text { (6) }\end{array}\end{array}$} & $\begin{array}{l}\text { Full Sample } \\
\text { 75th } \\
\text { (7) }\end{array}$ \\
\hline $\begin{array}{l}\text { 1. Displeced from } \\
\text { Airline Industry }\end{array}$ & $\begin{array}{l}-0.003 \\
(0.043)\end{array}$ & $\begin{array}{l}-0.002 \\
(0.043)\end{array}$ & $\begin{array}{l}-0.012 \\
(0.045)\end{array}$ & $\begin{array}{l}0.016 \\
(0.059)\end{array}$ & $\begin{array}{l}-0.035 \\
(0.036)\end{array}$ & $\begin{array}{l}-0.002 \\
(0.044)\end{array}$ & $\begin{array}{c}0.044 \\
(0.044)\end{array}$ \\
\hline \multicolumn{8}{|l|}{ Other Controls: } \\
\hline 2. Age at Displacenent & $\cdots$ & $\begin{array}{l}-0.005 \\
(0.002)\end{array}$ & $\begin{array}{l}-0.005 \\
(0.002)\end{array}$ & $\begin{array}{c}0.010 \\
(0.003)\end{array}$ & $\begin{array}{l}-0.004 \\
(0.002)\end{array}$ & $\begin{array}{l}-0.016 \\
(0.002)\end{array}$ & $\begin{array}{c}0.026 \\
(0.002)\end{array}$ \\
\hline $\begin{array}{l}\text { 3. Age at Displ acement } \\
\text { squared }(\times 10,000)\end{array}$ & $-\cdot$ & $\begin{array}{l}-0.015 \\
(0.287)\end{array}$ & $\begin{array}{l}-0.005 \\
(0.288)\end{array}$ & $\begin{array}{l}-1.940 \\
(0.388)\end{array}$ & $\begin{array}{l}0.137 \\
(0.231)\end{array}$ & $\begin{array}{l}1.370 \\
(0.278)\end{array}$ & $\begin{array}{l}-4.879 \\
(0.225)\end{array}$ \\
\hline 4. Education & $\cdots$ & $\begin{array}{c}0.013 \\
(0.002)\end{array}$ & $\begin{array}{c}0.014 \\
(0.002)\end{array}$ & $\begin{array}{c}0.016 \\
(0.002)\end{array}$ & $\begin{array}{c}0.011 \\
(0.001)\end{array}$ & $\begin{array}{c}0.011 \\
(0.002)\end{array}$ & $\begin{array}{c}0.035 \\
(0.002)\end{array}$ \\
\hline 5. Previous Tenure & $-\cdot$ & $\begin{array}{l}-0.012 \\
(0.001)\end{array}$ & $\begin{array}{l}-0.012 \\
(0.001)\end{array}$ & $\begin{array}{l}-0.013 \\
(0.001)\end{array}$ & $\begin{array}{l}-0.010 \\
(0.001)\end{array}$ & $\begin{array}{l}-0.009 \\
(0.001)\end{array}$ & $\begin{array}{l}-0.009 \\
(0.001)\end{array}$ \\
\hline 6. Female Dumay & $\cdots$ & $\begin{array}{l}-0.004 \\
(0.008)\end{array}$ & $\begin{array}{l}-0.004 \\
(0.008)\end{array}$ & $\begin{array}{l}-0.035 \\
(0.012)\end{array}$ & $\begin{array}{l}-0.001 \\
(0.007)\end{array}$ & $\begin{array}{l}0.030 \\
(0.008)\end{array}$ & $\begin{array}{l}-0.041 \\
(0.008)\end{array}$ \\
\hline 7. Monwhite Dummy & -- & $\begin{array}{l}-0.007 \\
(0.013)\end{array}$ & $\begin{array}{l}-0.007 \\
(0.013)\end{array}$ & $\begin{array}{c}0.006 \\
(0.018)\end{array}$ & $\begin{array}{c}0.015 \\
(0.010)\end{array}$ & $\begin{array}{c}0.002 \\
(0.013)\end{array}$ & $\begin{array}{l}-0.107 \\
(0.011)\end{array}$ \\
\hline 8. Year Dumies & - & yes & yes & yes & yes & yes & yes \\
\hline 9. Sample size & 21,625 & 21,625 & 21,589 & 21,625 & 21,625 & 21,625 & 35,284 \\
\hline
\end{tabular}

Hotes: Estimated standard errors in parentheses. Sample in colums 1-6 consists of individuals in the 1984, 1986, 1988, 1990, 1992, or 1994 Displaced Worker Surveys who reported a valid pre-displacement wage, were re-employed at the time of the Survey, and reported a valid wage for the main job at the time of the survey. The dependent variable is the change in the log of the wage (pre- and post-displacement wages are inflated to constant 1994 dollars). Sample in colum 7 adds in individuals who reported a valid re-displacenent wage but tho were not re-eaployed at the survey date. For these individuals the change in log wages is (arbitrarily) set to -2.0 . 
Table 10: OLS and Quantile Regression Models for Change in Wage Following Job Displacement

\begin{tabular}{|c|c|c|c|c|c|}
\hline & \multicolumn{2}{|c|}{ OLS Models: } & \multirow{2}{*}{\multicolumn{3}{|c|}{ Quantile Regressions: }} \\
\hline & & & & & \\
\hline & $\begin{array}{l}\text { All } \\
(1)\end{array}$ & $\begin{array}{l}\text { Pilots } \\
\text { (2) }\end{array}$ & $\begin{array}{c}25 \text { th } \\
(3)\end{array}$ & $\begin{array}{c}50 \text { th } \\
(4)\end{array}$ & $\begin{array}{c}75 \text { th } \\
(5)\end{array}$ \\
\hline 1. Change Industry & $\begin{array}{l}-0.116 \\
(0.009)\end{array}$ & $\begin{array}{l}-0.116 \\
(0.009)\end{array}$ & $\begin{array}{l}-0.234 \\
(0.013)\end{array}$ & $\begin{array}{l}-0.077 \\
(0.007)\end{array}$ & $\begin{array}{l}-0.005 \\
(0.009)\end{array}$ \\
\hline $\begin{array}{l}\text { 2. Displaced from } \\
\text { Airline Industry }\end{array}$ & $\begin{array}{l}-0.079 \\
(0.067)\end{array}$ & $\begin{array}{l}-0.086 \\
(0.074)\end{array}$ & $\begin{array}{l}-0.082 \\
(0.088)\end{array}$ & $\begin{array}{l}-0.057 \\
(0.052)\end{array}$ & $\begin{array}{l}-0.022 \\
(0.062)\end{array}$ \\
\hline $\begin{array}{l}\text { 3. Interaction: Industry } \\
\text { Change } x \text { Displaced } \\
\text { from Airline Ind. }\end{array}$ & $\begin{array}{l}0.100 \\
(0.087)\end{array}$ & $\begin{array}{l}0.096 \\
(0.094)\end{array}$ & $\begin{array}{l}0.134 \\
(0.114)\end{array}$ & $\begin{array}{l}-0.004 \\
(0.067)\end{array}$ & $\begin{array}{c}0.038 \\
(0.081)\end{array}$ \\
\hline $\begin{array}{l}\text { Implied Effects Relative to } \\
\text { Average Displaced Worker": }\end{array}$ & & & & & \\
\hline 4. Alrline $\rightarrow$ New Industry & $\begin{array}{l}-0.008 \\
(0.053)\end{array}$ & $\begin{array}{l}-0.019 \\
(0.057)\end{array}$ & $\begin{array}{l}-0.006 \\
(0.069)\end{array}$ & $\begin{array}{l}-0.080 \\
(0.041)\end{array}$ & $\begin{array}{l}0.015 \\
(0.049)\end{array}$ \\
\hline 5. Airline $\rightarrow$ Airline & $\begin{array}{l}0.008 \\
(0.071)\end{array}$ & $\begin{array}{l}0.001 \\
(0.079)\end{array}$ & $\begin{array}{l}0.094 \\
(0.095)\end{array}$ & $\begin{array}{l}0.000 \\
(0.055)\end{array}$ & $\begin{array}{l}-0.018 \\
(0.067)\end{array}$ \\
\hline
\end{tabular}

Notes: Sample consists of individuals in the 1984, 1986, 1988, 1990, 1992, or 1994 Displaced Worker Surveys who reported a valld pre-displacement wage, were re-employed at the time of the Survey, and reported a valid wage for the main job at the time of the survey. The dependent variable is the change in the log of the wage (pre- and post-displacement wages are inflated to constant 1994 dollars). All models include 11 additional covariates (age at job displacement and its square, education, predisplacement tenure, indicators for female, nonwhite, and survey year). Sample size in columns 1 and $3-5$ is 21,625 . Sample size in column 2 (which excludes any Individuals whose pre-displacement occupation was pilot) is 21,589 .

aRow 4 shows the estimated differential between an airline worker who changes industry post-displacement, and an "average" worker displaced from non-airline industries. Row 5 shows the estimated differential between an airline worker who is re-employed in the airline industry postdisplacement, and an "average" worker displaced from non-airline industries. 